\title{
TEChNOLOGICAL CHANG AT PLATYPUS ROCKSHELTER (KB:A70), SOUTHEAST QUEENSLAND
}

\author{
PETER HISCOCK and J. HALL \\ Anthropology \& Sociology. \\ Univergity of Queensland
}

\section{INTRODUCTION}

Platypus Rockshelter yielded a rich and varied assemblage of stone artefacts. In this paper we describe temporal change in the artefact assemblage and, by implication, prehistoric technology, concentrating particularly on the evidence for chert stoneworking. Readers are referred to accompanying papers by Hall et al (1988) and Hall and Hiscock (1988) in this volume of QAR for details of the stratigraphy and dating of the site. What ia important to reiterate here is that the deposit provides a discontinuous sequence of occupation dating back to approximately 5300 years BP. This, plus the fact the radiocarbon samples were selected to date stratigraphic transitions, means that the artefactual sequence is divided into a number of sharply-bounded analytical units, and change can be identified between but not within these units. The necessity for the cultural sequence to be subdivided in this way makes it likely that gradual changes in prehistory will be seen as episodic, and that each unit may be a compilation of a number of discrete occupation events (cf. Frankel 1988). Thus, while we employ strata as minimal units of comparison in the artefactual analysis, we make no assumptions about the uniformity within, and rate of change between, those units. The purpose of the paper 1 s to characterize the long-term changes in the technology of the inhabitants of the site.

\section{ASSEMBTAGE COMPOSITION}

Seven classes of artefact were recognised in the assemblage from Platypus Rockshelter. Chipped stone artefacts were identified using the characteristics suggested by Hiscock (1984:128): ringcracks, bulbs of force, eraillure scars beneath platforms, and negative flake scars. Five types of chipped artefacts were defined as follows:

Cores are nodules of stone from which fragments have been detached by blows. They contain one or more negative flake scars but no positive flake scars.

Flakes are those pieces of stone struck off a core. They have a series of attributes showing they have been struck. The most indicative of these are ringcracks, showing where the hammer hit the core. The ventral surface may also be deformed in particular ways, for example a bulb or erail lure scar.

Retouched Flakes are those flakes which have had fragments detached by blows, identified by flake scars on the ventral face and/or deriving from the ventral face. 
Flaked Pieces are chipped artefacts with negative flake scars which cannot be classified as a flake, core, or retouched flake.

Eraillure flakes form between the bulb of force and the bulbar scar. They are convex/concave (like a meniscus lens), have no distinct features on the "dorsal face", but may contain compression rings and portions of the cone on the bulbar face.

Ground artefacts, those which had abraded surfaces, were subdivided into two artefact types. Grindstones are those with the abraded area positioned in the centre of a surface. Axes characteristically contain two ground surfaces which meet at a bevel.

Using these categories, the 1728 artefacts larger than $5 \mathrm{~mm}$ can be described and changes in assemblage composition identified (Table 1 ). Eraillure flakes, grindstones and axes occur in such.small numbers that no chronological changes can be identified. Unretouched flakes remain the most common artefact type throughout, although their frequency varies. The most dramatic changes in assemblage composition are those involving retouched flakes, flaked pieces, and cores. Figure 1 illustrates three chronological trends in assemblage content. Retouched flakes became proportionately more frequent through time. It will later be shown that these changes are paralleled by increasing diversity of the types of retouched flakes produced, suggesting a gradual shift in the production and use of such artefacts.

\% retouched flakes
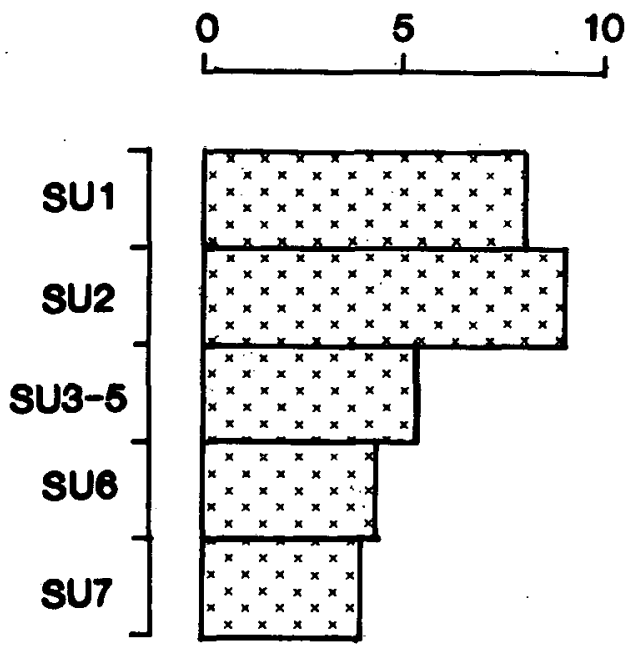

\% flaked pieces
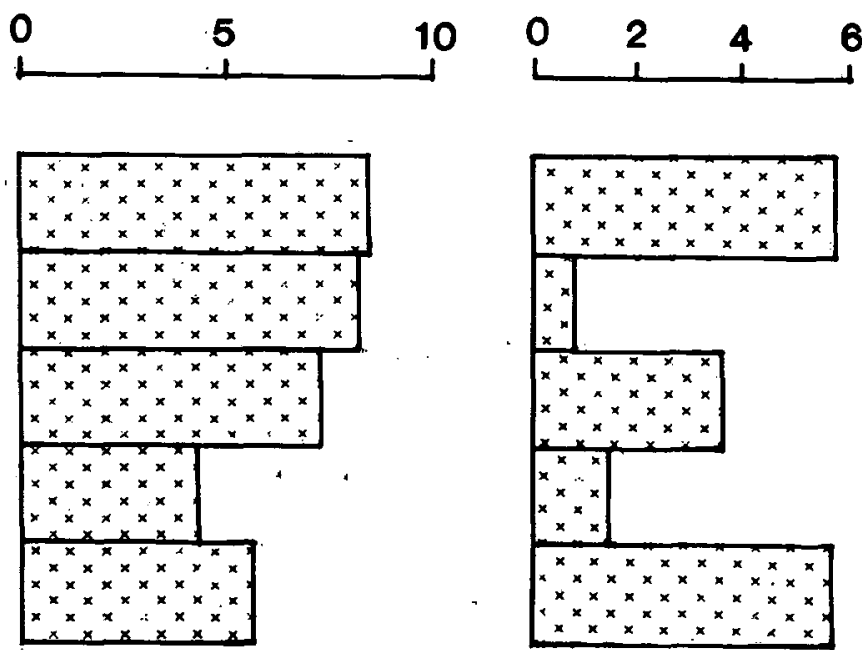

\% cores

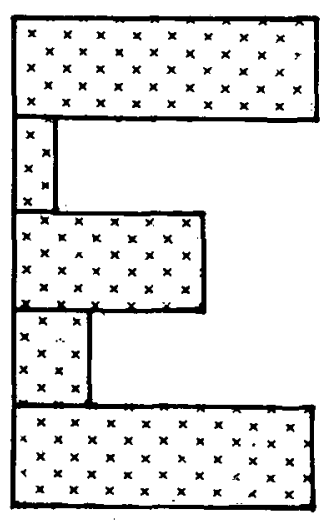

Figure 1. Vertical trends of retouched flakes, flaked pieces and cores at $\mathrm{KB}: \mathbf{A 7 0}$.

The second chronological change illustrated in Figure 1 is the gradual increase in the proportion of flaked pieces, which are most common towards the surface of the deposit. This pattern is probably a result of two factors. Flaked pieces are much more frequent on some raw materials than on others, and so a shift in raw material procurement might result in changes in the proportion of flaked pieces within the assemblage. For example, flaked pieces are more than twice as frequent on quartz as on any other rock type, and more artefacts are made from quartz at the top of the deposit (14.48) than at the bottom (10.88). 
Exaggerating the effects of these raw material changes is the chronological changes in taphonomic processes operating on stone artefacts within the shelter. The majority (52\%) of flaked pieces have been heat-shattered, compared with only 19.78 of other artefact classes. Thus, heat-shattering is a prominent factor creating difficulties in artefact recognition and leading to specimens being placed in the flaked piece category. Heat-shattering of artefacts is much more frequent in su 1-5 (14.2-21.18) than in SU 6-7 (5.9-6.98). Consequently, flaked pieces are more common in the upper, levels of the deposit.

The third trend shown in Figure 1 is a low frequency of cores in su 2-6. As the frequency of cores varies between raw material types, this pattern is actually a compilation of a number trends. For example, the proportion of quartz artefacts which are cores ranges from 5.08 in sU6 to 18.68 in SU1, while the proportion of chert artefacts which are cores increases from only $1.8 \%$ in sU6 to $5.1 \%$ in sul. These differences result from the relationship between rock type and the size of nodules and the number of flakes that were struck from each. The precise composition of the assemblage at any level in the deposit therefore depends on the nature of raw material procurement and use. Nevertheless,. most raw materials show an increase in the relative frequency of cores through time, suggesting technological change.

Stone artefacts in the assemblage were usually made from seven rock types: chert, mudstone, quartzite, silcrete, basalt, quartz and silicified wood (Table 2). Throughout the deposit chert and quartzite are the most common raw materials employed for artefact manufacture. A small number of specimens were made from other rock types, such as granite or sandstone, or were too encrusted to be identified (called 'other' in Table 2). A review of available geological information indicates that all of these materials may have been procured locally.

\section{GEOLOGICAI BACKGROUND AND RAW MATERIAI PROCUREKENT}

In the vicinity of platypus Rockshelter, the Brisbane River is confined to a one kilometre wide flood plain which runs along the western edge of the Great Moreton Fault (Hill 1930). East of this fault uplifted sediments of the D'Aguilar Block, primarily the Palaeozoic Neranleigh-Fernvale Beds, form steep hills up to $600 \mathrm{~m}$ high. West of the Brisbane River, and to the north of the site, lower undulating terrain has formed on a variety of Mesozoic sediments.

All of the stone material employed in artefact manufacture at KB:A70 outcrops in.sediments within $10 \mathrm{~km}$ of the shelter. The lithology and derivation of these sediments is as fol lows. -.

Neranleigh-Fernivale Beds are conglomerate lenses containing rounded pebbles and boulders of.shales, chert, quartzite, mudstone, greywacke and basic volcanics (Cranfield et al 1976:17; O'Flynn et al 1983; Tucker 1961). Chert is especially. common in the vicinity of platypus shelter.

Northbrook Beds consist of sandstone, shale, and volcanic conglomerate interbedded with minor amounts of siltstone, chert, basalt, andesitic tuffs and dacitic tuffs (Cranfield et al 1976:31; O'Flynn et al 1983:6).

Bryden Formation consists primarily of sandstone, shale and pebble to cobble sized conglomerate. The conglomerate contains chert, silicified sandstone, quartzite and occasionally igneous pebbles (Cranfield et al 
1976:37; O'Flynn et al 1983:8). This material was probably eroded from outcrops of the Neranleigh-Fernvale Beds and deposited in low-lying areas by streams, eventually creating the Bryden Formation. Consequently the flakeable material is similar in both strata.

Bsk Formation also consists of sandstone, shale and conglomerates reworked from the Neranleigh-Fernvale Beds (Cranfield et al 1976:40). the Esk Formation differs from the Bryden Formation by having boulder sized conglomerate, and by being poorer in quartzose cobbles but richer in basic volcanic ones. Interspersed amongst these sediments are acid tuff horizons caused by volcanism near Esk (zimmerman 1956).

Marburg Formation also results from rapid erosion of the NeranleighFernvale Beds and deposition of sediments in a fluviatile environment, but the size class of rock material is relatively small. Sandstone, siltstone, mudstone and occasionally conglomerates occur in near horizontal beds (Cranfield et al 1976:63). The conglomerate is pebble sized and consists of chert, quartzite, mudstone, basalt, mudstone and acid volcanics. Small amounts of silicified wood may also occur in the conglomerate (O'Flynn et al 1983:10).

The Marburg Formation and Belidon Sandstone are known to have been extensively laterized, forming silcrete caps in some locations (Craníleld et al 1976:60, 63). Although no extensive silcrete surfaces have been mapped in the vicinity of Platypus shelter field investigations showed that rounded nodules of silcrete are available.

Immediately downgtream from the shelter was an extensive gravel bed. As dam construction and subsequent flooding has since inundated this area in the vicinity of the site it was not possible to assess the potential of the local river gravels as a source of the archaeological artefacts. Examinations of similar gravel banks downstream, however, show that cobbles and pebbles of chert, quartzite, basalt and quartz all occur in the bed of the Brisbane River.

\section{CERonotogicat charge IN RAH MATERIAL USAGE}

Although chert and quartzite were the stone materials most commonly used at all periods at Platypus shelter, there were temporal changes in raw material usage. The changes are complex, but generally the lower and upper levels of the deposit. have similar raw material proportions, whereas the frequency of rock types used in su3-5 are distinctly different. During the earliest period of occupation, igneous artefacts (basalt and quartz) were uncommon (Figure 2a). Artefacts made on igneous rocks occurred in increasingly higher proportions, peaking in su3-5, and then decreased again in the upper levels of the site. These chronological trends were caused by a greater use of basalt in the central portion of the deposit, particularly su 3-5, than in higher and lower levels (Figure 2b). In the stratigraphic units in the middle of the deposit, basalt replaced not only sedimentary rock, but also quartz (Eigure $2 \mathrm{c}$ ).

These changes were paralieled by shifts in the use of one sedimentary rock type over another. Chert and quartzite were used in roughly equal amounts during the early and late occupation of the site. In contrast, chert was used much more than quartzite during the middle phase of occupation, centred around su 3-5 (Figure 2d). 


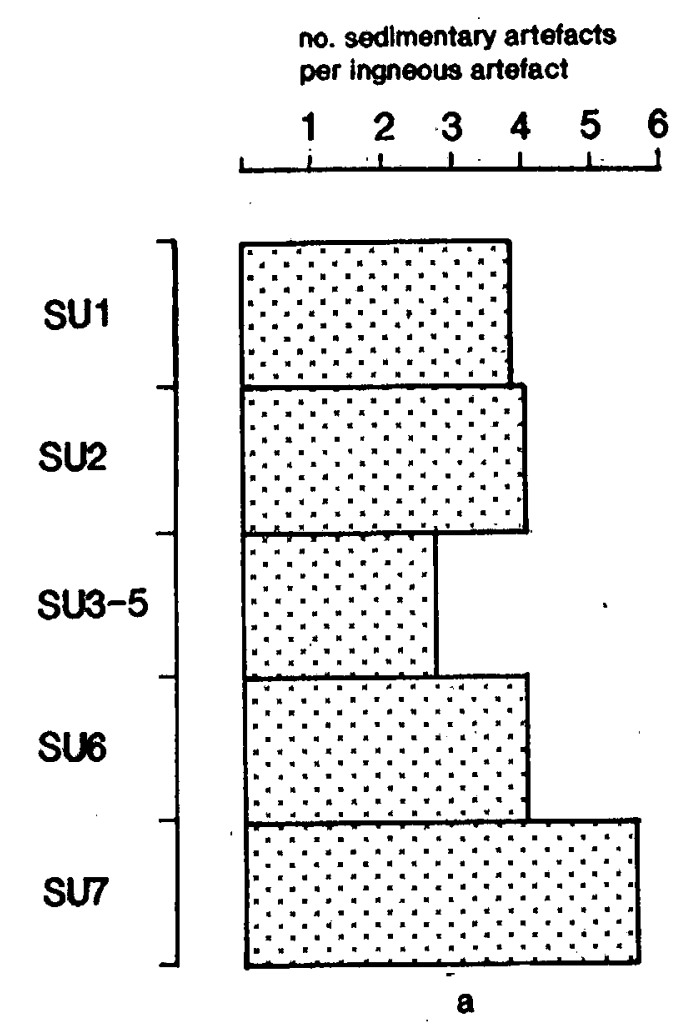

no. sedimentary artefacts per basalt artefact
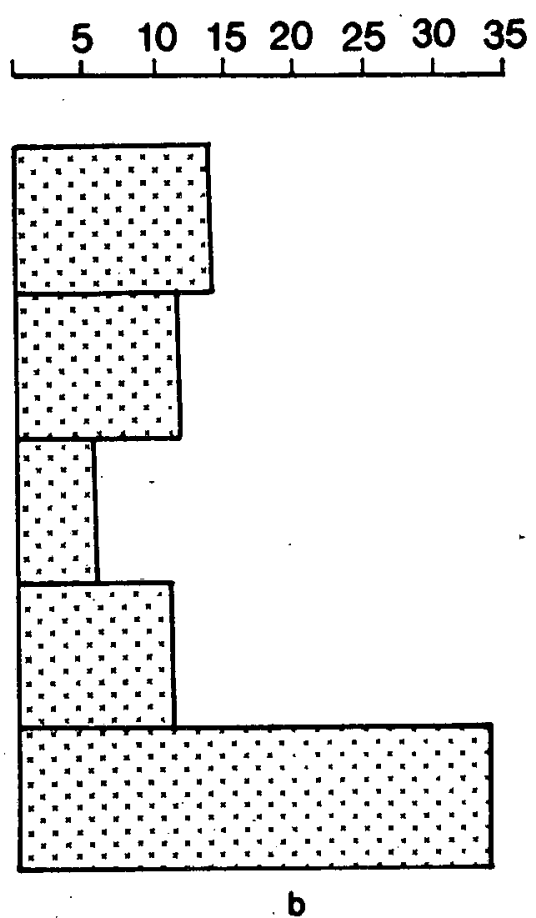

no. quartz artefacts per besalt artefact
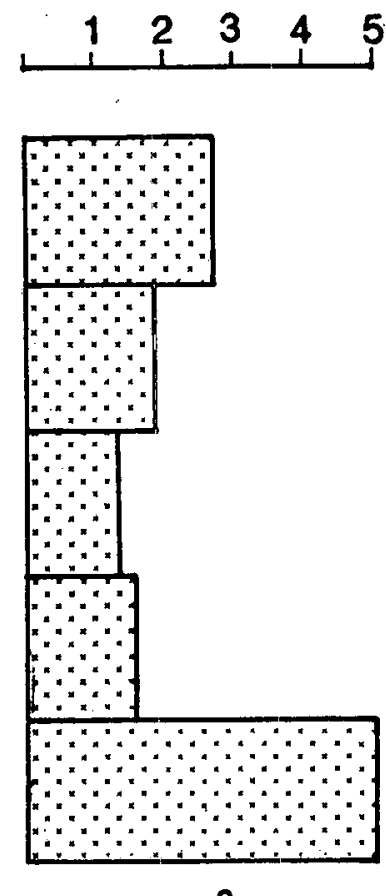

no. chert artefacts per quartzite artefact
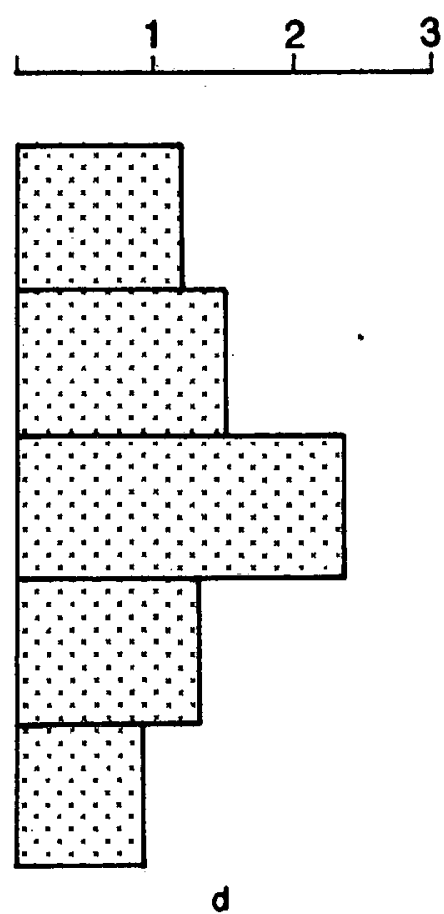

Figure 2. Temporal changes in stone raw material at KB:A70. 
For the purposes here, the chronological changes in raw material usage can therefore be characterised in the following way. In the lower levels the assemblage is igneous poor, with roughly balanced amounts of quartzite and chert. At later times the assemblage became relatively rich in chert and basalt, and depleted in quartz and quartzite compared to other periods. Assemblages in the recent past are somewhat like those in the earliest period, in that chert and quartzite occur in almost equal amounts and igneous rocks were less common. Igneous materials, particularly basalt, however; remain in higher frequencies at the top of the deposit than in the base.

While this describes the temporal variation in stone procurement and use, the histograms employed in Figure 2 probably overemphasize the sharpness of change. In all cases there is a gradation from su7 to SU3-5 and then to sul (eg. Figure 2d). This suggests that the chronological changes in raw material usage were likely to have been gradual rather than abrupt.

\section{EFFECTS OF RAT MATERIAL}

Artefact size and morphology is often atrongly related to the raw material from which it is made. To quantify the effects of raw material properties on artefact form at Platypus Rockshelter, a number of measurements were made of unretouched flakes. The attributes employed are defined in the appendix. Tables 3-5 give descriptive statistics for the size and shape of flakes in su6. Tables 6-8 provide similar data for su3-5. There is a great deal of variation within raw material types and between the strata, and it should be stressed that for many attributes, raw material type appears to have little influence. For example, the frequency of elongate flakes ( $L 2 W$ ) made on quartz is equal to, or higher than, the frequency of those on chert, quartzite, and basalt. Nevertheless, there are differences between the rock types, and four general relationships are noteworthy:

1. Quartz flakes are on average much smaller than flakes made on the other materlals. They are also relatively thick.

2. Silcrete flakes are on average, larger than flakes made on other materials. They have very few elongate flakes.

3. Chert and quartzite flakes are on average broadly similar in size, especially with regard to platforms. They also have similar shapes.

4. Basalt flakes are on average the same size or larger than chert and quartzite.

Differenceg between raw material typeg are also apparent in the non-metrical characteristics of flakes (Tables 9 and 10 ). Again chert and quartzite can be seen as similar relative to basalt and quartz. Basalt is distinctly different from quartz. The major patterns of nonmetrical attributes can be summarized as follows:

1. Quartz flakes exhibit little core preparation. They rarely have focalized platforms, and never have faceting or overhang removal.

2. Silcrete flakes contain a moderate amount of core preparation, and the majority have cortex on their dorsal face. 
3. Chert and quartzite. flakes were often otruck from high angled cores which had sometimes been extensively prepared by faceting or overhang removal.

4. Basalt flakes were struck from low angles cores by imprecisely located blows. Flakes contain moderate frequencies of overhang removal and faceting.

5. The stone types with macroscopic grains or extensive healed cracks, such as quartzite, silcrete and quartz, have higher frequencies of step terminations than chert or basalt.

Differences between the assemblages in SU6 and SU3-5 indicate which raw material types best reveal technological change. Chert and quartzite show extensive temporal alteration in the frequency of attributes describing the flake platform, such as faceting or overhang removal. In contrast, chronological change in such attributes is minimal on basalt and quartz. Basalt, however, undergoes the greatest changes in artefact shape and size.

On this basis it was decided to describe chronological changes in stoneworking technology by concentrating upon the analysis of chert flakes. Chert is the most abundant raw material represented in the asemblage, and sufficient numbers exist in all strata to permit statistical investigation. Furthermore, chert appears to reflect subtle changes in the application of blows and core preparation, but to be 1 ess variable in artefact size than other rock types.

\section{CHRONOLOGICAL CHANGES IN CHERT STONEWORKING}

Changes in the reduction system employed to manufacture chert artefacts was asgessed by an analysis of attributes on complete unretouched chert flakes larger than 5mm. Tables $11-13$ provide descriptive statistics of flake size and shape for each of the five sets of stratigraphic units. In almost all of the traits which were measured, the size and shape of artefacts at the top and the base of the deposit are similar but distinct from those in the central levels, particularly su3-5. Average flake weight and ventral surface area are lowest in su35, higher in su6 and sU7, and highest in sUl (Table 11). This trend does not reflect changes to mean flake length, which increaseg slightly throughout the sequence, but is primarily a response to temporal variation in flake width and thickness (Table.11). Flake thickness is lowegt in sU3-5, higher in SU2 and SU6-7, and markedly higher again in SUl (Table 11). Flake platforms are small in su2 and su3-5, but larger in higher and lower levels of the deposit (Table 12). Flakes in the bottom and top of the sequence are on average more squat, less parallel, and relatively thicker than those in su2 and su3-5 (Table 13 ).

Related to these trends in flake size and shape are technological changes in the frequency of some knapping procedures (Table 14):

1. There is a tendency for more flakes to have low platform angles in su3-5 and su6 compared with other strata.

2. The frequency of focalized platforms increases through the sequence, peaking in SU2, but declines markedly in the recent past. Focalized platforms result from the placement of blowg near the edge of the 
core platform, and consequently the chronological changes in flake platform thickness parallels those of focalized platforms (cf. Table 12). The frequency of platform shattering displays a similar trend, indicating that locating blows close to the edge of the core platform increased the likelihood of shattering.

3. Faceting is not found in SU7, but occurs in higher levels. Faceting becomes relatively common in sU3-5, replacing surfaces with several scars. The increase in platform faceting at this level may be interpreted as the knappers response to the need for more precise blow location near the core edge, and an attempt to avoid platform shattering.

4. Overhang removai is relatively common in SU3-5 and SU6, and becomes less frequent in later levels.

5. Outrepasse terminations occur only in sU3-5 and sU6, suggesting that inward directed blows may have been more common than in earlier or later times.

6. Amaller proportion of flakes contained cortex in sU2 and SU3-5 than in higher and lower strata. This pattern is probably related to the relatively small flake size in those levels, and may indicate a greater emphasis on later stages of reduction. One mechanism by which a decrease in decortication flakes might be brought about is the knapping of retouched flakes rather than cores. Figure 3 demonstrates that the ratio of burin-like retouched flakes to cores is much higher in SU2 and SU3-5 than in other levels, suggesting that the decrease in decortication flakes in those strata is partly a result of a switch away from cores. The increased use of burinlike retouched flakes as a source of flakes may also partly explain the emphasis in SU2 and SU3-5 of precise location of blows close to the core edge, and the production of relatively thin, elongate flakes.

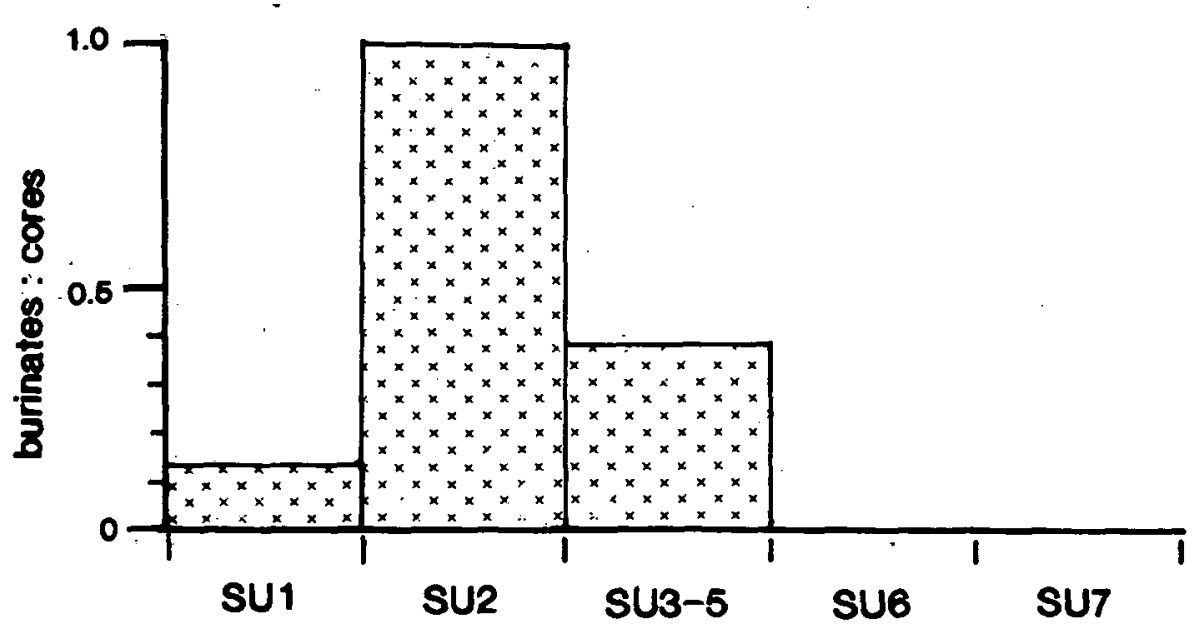

Figure 3. Changes in the ratio of burinates to cores at KB:A70.

These changes in knapping practices can be offered as an explanation of the temporal differences in raw material procurement which were described above. It was earlier concluded that the central portion of the deposit, especialiy su3-5, is rich in chert and basalt artefacts relative to other strata. It was also noted that these two 
rock types yielded fewer step terminations than other types which were knapped in the shelter. In SU2 and sU3-5 the artefact assemblage indicates that knappers were applying precise blows to small retouched flakes. In such endeavours it would be advantageous to avoid step terminations, and it may be that the change in stone procurement reflects an attempt to select the most suitable materials for the job. Similarly, at later times, when knapping commonly involved applying less precise blows to cores, there may have been fewer constraints on the selection of raw materials.

It has been noted that in many ways there is a symmetry to the chronological changes at Platypus Rockshelter, with similar stone procurement and reduction strategies being employed during the earliest and latest phases of occupation. Not all aspects of artefact manufacture and use display such symmetry. For example, overhang removal is more common in the central and lower levels of the deposit, below su2, than in the upper levels. Similar non-symmetrical patterns are observed in describing the temporal changes in retouched flakes and usewear.

\section{CHRONOLOGICAC CHANGE IN RETOUCHED FLAKES}

Eight classes of retouched flakes were recognised in Platypus Rockshelter. Backed blades were flakes steeply, and often bidirectionally, retouched along one lateral margin (Figure 4a). Bloueras were similar to backed blades, although larger and thicker (Figure 4b). Double backed $f l a k e s$ were flakes steeply, and often bidirectionally, retouched long both lateral margins (Figure 4c). These double backed flakes resemble the 'drills' which have been reported from New Guinea (Allen 1977:443). Burrens were large, thick flakes with one or both lateral margins extensively flaked to form straight or concave low angled edges (Figure 4d). Tulas (Figure $4 \mathrm{e}$ ) were retouched flakes with wide platforms, pronounced bulbs, and retouched onto the dorsal face and at the distal end until only the bulbar portion remained (Hiscock 1988:63). Burinates were retouched flakes from which flakes had been struck along, and parallel to, the lateral or distal margins (Figure 4f). This retouching was sometimes accomplished using a bipolar technique, as in the illustrated specimen, but on other specimens it appears to have been acheived by hand-held direct percussion. Points were flakes which had the lateral margin and/or the proximal end retouched so that the plan shape contracts toward the distal end (Figure 4g). Amoxphous retouched flakes were those retouched flakes with small amounts of unifacial retouch and which did not clearly fall into either of the other categorieg of retouched flake (Figure' $4 \mathrm{~h}$ ). Sume specimens classified as amorphous retouched flakes may be unfinished versions of the types described above, while others are technologically distinct and cannot be intexpreted as incomplete examples of other forms of retouched flakes.

The numbers and raw materials of each of these types of retouched flakes are given in Table 15. Backed blades and amorphous retouched flakes are the most common types. Backing retouch was employed on all raw materials, but was used more frequently on some rock types than on others. Chert and quartzite were preferred for backed blade manufacture, while the other materials were used primarily for the production of amorphous retouched flakes. Chert was used for a much greater variety of retouched flakes than the other rock types. In comparison to the other. rocks, quartz flakes were retouched less frequently and in a smaller number of ways. 


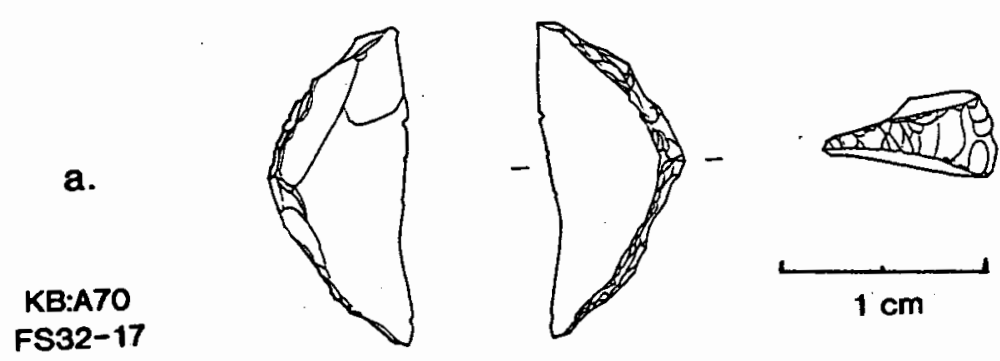

b.

KB:A70

FS 199-84
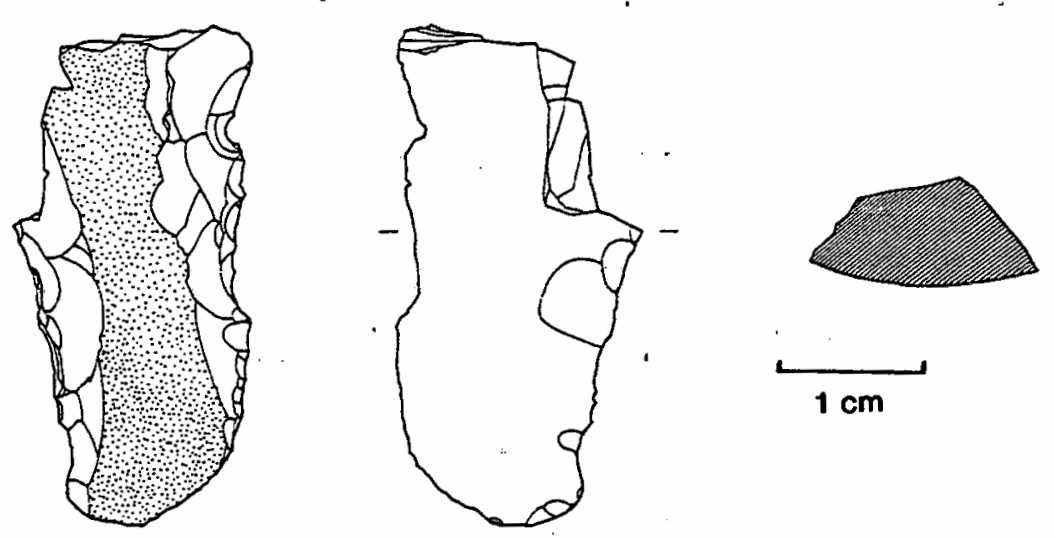

c.

KB:A70

FS26-18
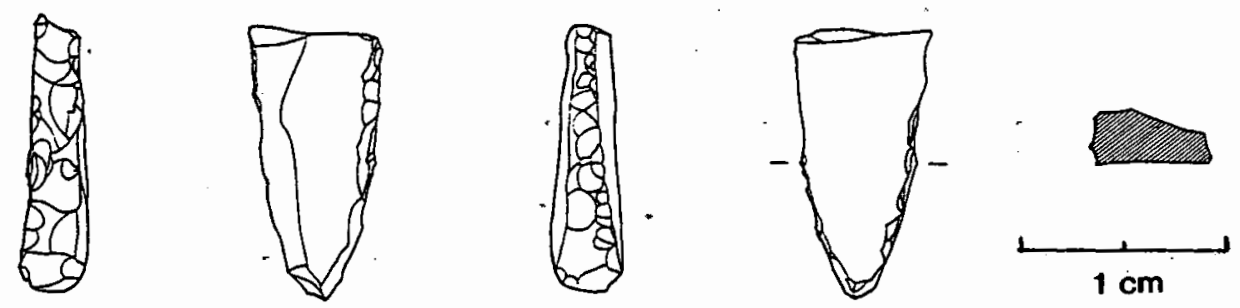

d.
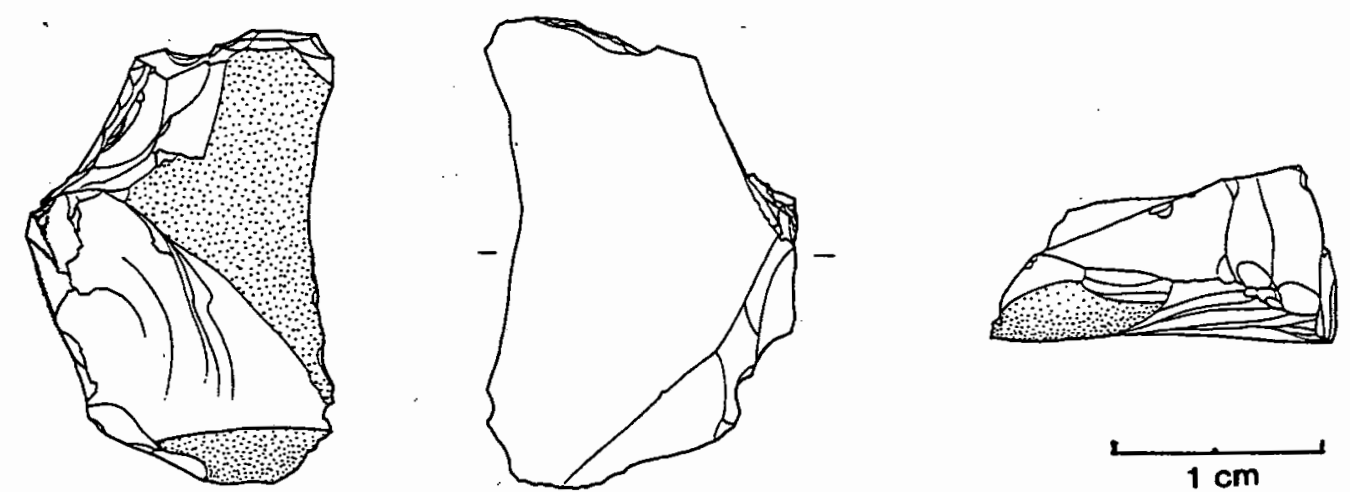

Figure 4. Examples of artefacts from RB:A70. a) Backed blade, b) elouera, c) double backed flake, d) burren, e) tula, f) burinate, g) point, h) amorphous retouched flake. 

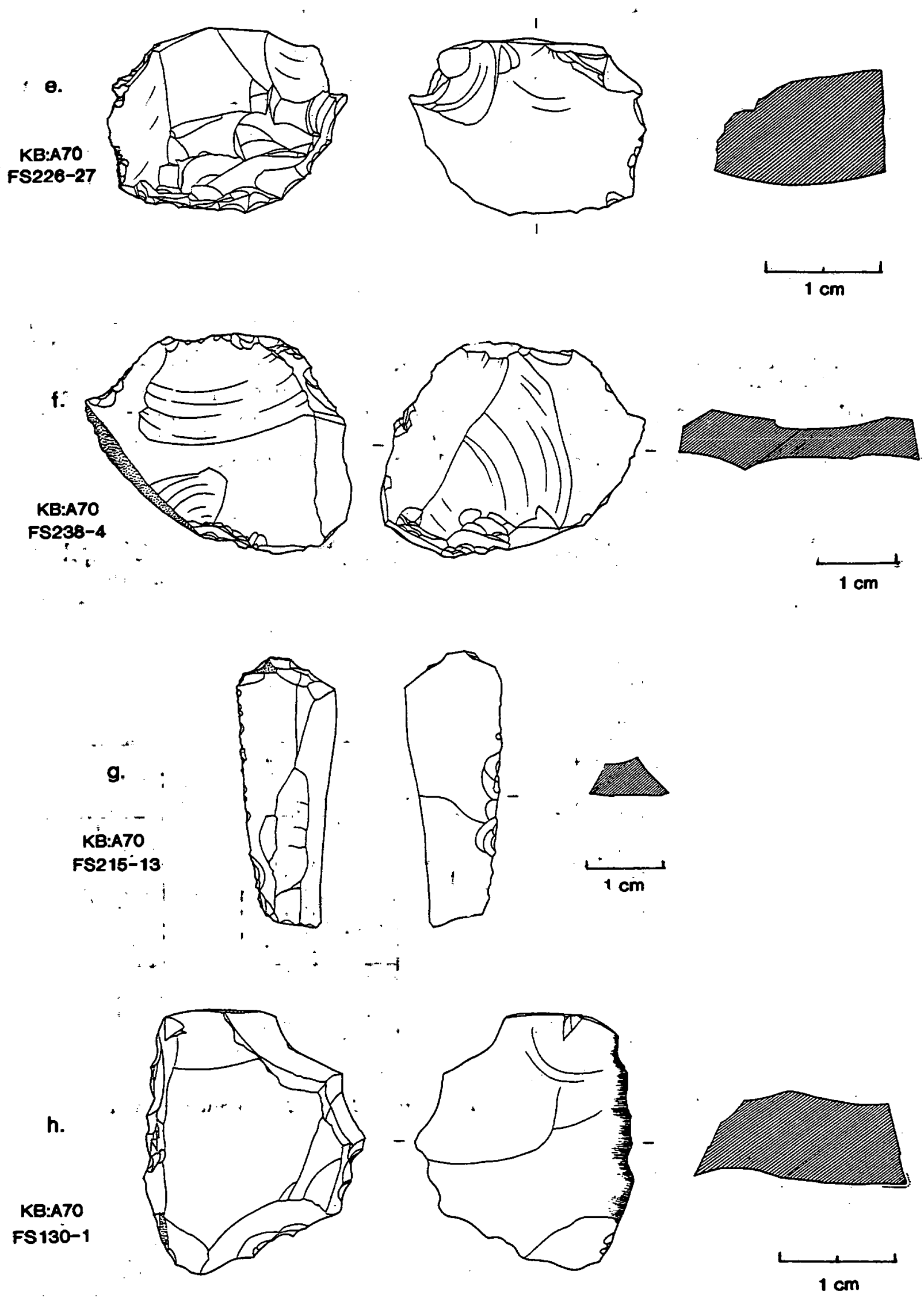

Figure 4. Continued 
The vertical distribution of retouched flakes is given in Table 16. Four chronological changes are noteworthy.

1. Retouched flakes become more common in the most recent strata (Figure 1).

2. The diversity of retouched flakes increases throughout the sequence, peaking in sul (Figure 5a). Only backed bladeg and amorphous retouched flakes were recovered from SU7, but in higher levels there are other types.

3. Burinates appear for the first time in su3-5, where they occur in relatively large numbers, and are less frequent in later levelg (Figure 5b).

4. Backed blades are found at all levels in the deposit, although their frequency varies. Expressed as a percentage of retouched flakes, backed blades are well represented in all strata except sul (Figure 5c). Expressed as a percentage of the entire assemblage, backed blades increase in frequency through the sequence, peaking in SU2, and are much less common in sul (Figure 5d). In either calculation it is apparent that the production of backed blades declined in the recent past, although they were still occasionally made.
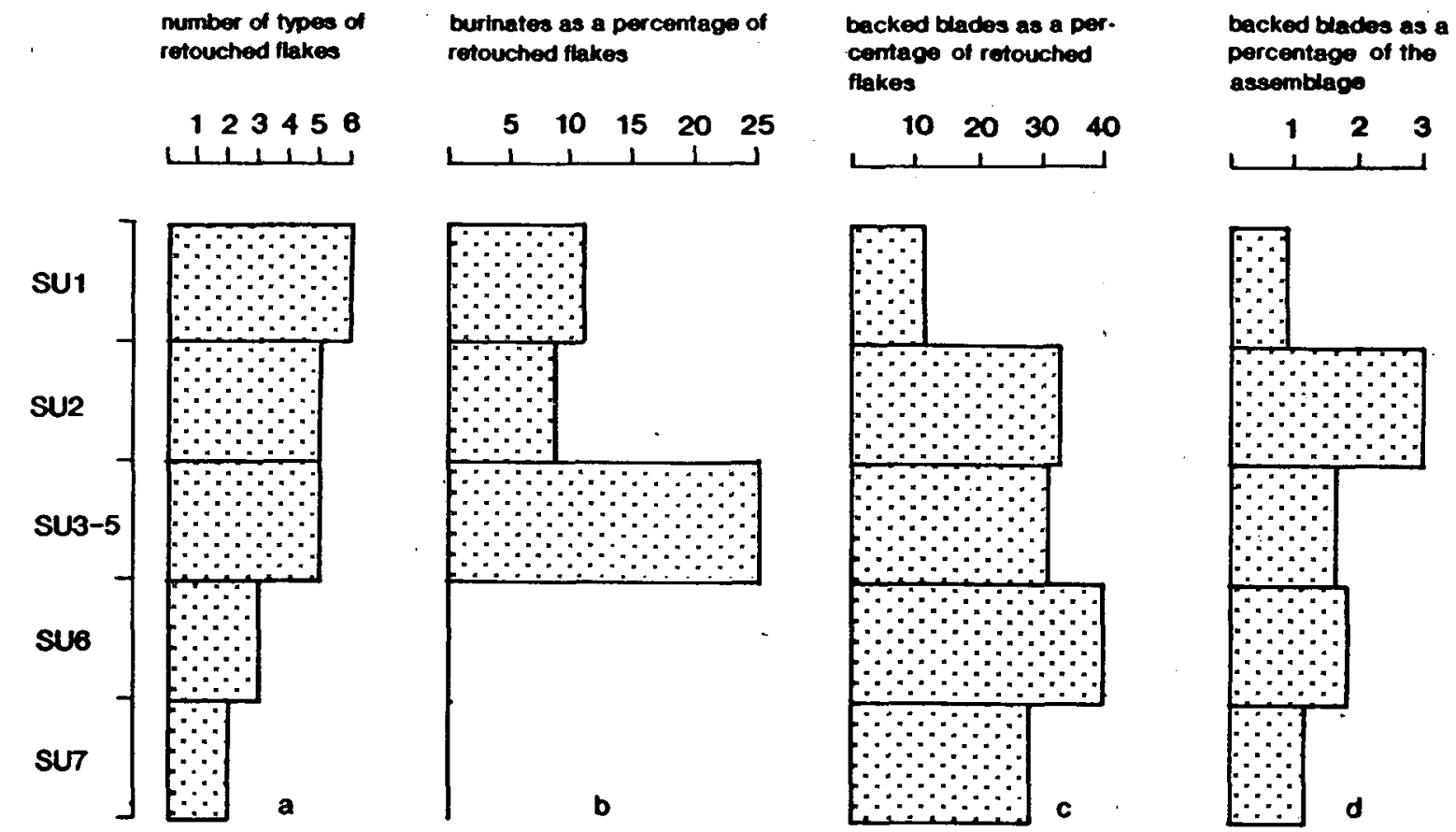

Figure 5. Changes in the frequency and diversity of retouched flakes at KB : $\mathbf{A 7 O}$.

These patterns indicate that during the last 2,500 years (SU1-5) there was a expansion of the role of retouched flakes within the stoneusing technology of the sites inhabitants. The increase in the relative frequency of retouching may partly reflect greater resharpening of tools, but it also reflects the greater number of 'opecialised' types, as demonstrated by the increasing diversity of retouched flake classes 
(Figure 5a). Some of these distinctive forms of retouched flakes, such as the double backed flakes, were specifically manufactured and may have been used in a restricted range of functions. Other forms of retouched flakes, such as the burinates, probably acted as a source of flakes and may not have been used. Declining production of backed blades relative to other classes of retouched flake in sul may reflect an alteration of the activities carried out at the site, a change in location of backed blade discard or the replacement of backed blades by some functionallyequivelent artefact. Usewear investigations will be needed to enhance our understanding of these trends.

\section{CHRONOLOGICAI, CHANGB IN USEWEAR}

Comprehensive usewear investigations have not been carried out on the assemblage, but one distinctive form of usewear has been studied. A number of flakes have rounding of the platform edge, where the platform and dorgal surfaces meet, and well developed gloss on the platform surface and the proximal end of the dorsal face. In all instances where the glose reaches the lateral margin of the flake it is truncated by the ventral surface, indicating that the wear was created before the flake was struck from the core. Such specimens were termed Gope (gloss on platform edge) flakes, and it is likely that they represent debris created by flaking a tool which had been used in processing silica-rich plants.

The chronological changes in the frequency, of GOPE flakes are quantified in Table 17. They are most common prior to 2500 years BP, in sU6, and least common in su3-5. In SU1 and su2 they again become more frequent compared to other components of the stone assemblage. Thus, although found in all levels of the deposit, variations in the frequency of GOPE flakes suggests that the activities carried out in su3-5 were radically different to those in other strata. The nature of the difference is difficult to determine, but the paucity of GoPE $f$ lakes in su3-5 compared to sú6 probably indicates either a decrease in that form of plant processing or a decrease in tool resharpening.

\section{DIscussion}

It is commonly asserted that backed blades occurred in Australia only between 4,500 and about 1,000 years BP (eg.Johnson 1979). The evidence presented above suggests that at platypus Rockshelter backed blades were deposited at all times at which the site was occupied, including levels which were laid down in the last 1,000 years BP. Two backed blades were recovered from sul, the same strata from which a date of $560 \pm 60$ (Beta 3076) was obtained. One of these specimens comes from a level above the dated charcoal sample, while the other was recovered from a different trench and cannot be directly related to the dated sample. In situ vertical movement of these two artefacts is unlikely to account for their positioning within the deposit, but they may have derived from the erosion of earlier sediments at the rear of the shelter (cf. Hall et al 1988). Thus, although the stratigraphic information indicates that backed blades were deposited less than 500 years ago they may not have been made at that time. A similar situation exists at the Gatton and Maidenwell shelters, where Morwood (1986:98, 107) recovered backed blades in levels less than 1000 years old and dismissed them as the result of stratigraphic disturbance. There is reason to suspect that in each of these sites backed blades in surficial 
levels may have come from older strata, but the continuing discovery of such specimens makes it impossible to conclude that backed blade manufacture definitely ceased 1000 years ago: Further excavations in the Moreton Region should specificaliy investigate the context of backed artefacts in recent sediments, with a view to establishing the date at which they ceased being made.

With the possible exception of SU1, backed blades were discarded in all levels of the site. Despite this continuity in backed blade manufacture, there were changes in stone procurement, artefact manufacture and use. We argue above that many of these changes may be interrelated. The shift in raw material procurement towards the use of chert and basalt, centred on SU3-5, coincides with the precise reduction of small. and highly prepared retouched flakes. Simultaneously GOPE flakes become infrequent, implying alterations to the nature of tool use and/or plant processing activities. These changes may also occur at the same time $a s$ an increase in the amount of occupation (Hall and Hiscock 1988). The coincidence of these patterns suggests that between 1-2000 years BP and 3000 years BP there was a broadly based alteration to the economy and settlement of the people using Platypus Rockshelter. In this paper we have concentrated on a description of stoneworking technology, and until detailed faunal analyses are completed it is not possible to precisely define the nature of those economic changes.

What we can comment upon here is the relative independence of typological and technological changes. Since the analysis of flakes demonstrates that the reduction strategy changed through time, it is reasonable to hypothesise that al though backed blades were common in each otratigraphic unit they may have been made in different ways. Archaeological analyses elsewhere in Australia have yielded similar suggestions (Hiscock 1986). This conclusion raises a number of questions which may be addressed in further studies.

1. If there are chronological changes in the nature of backed blade production; is this reflected in the morphology of backed blades themselves?

2. How many different technologies are used to manufacture backed blades in the Moreton Region?

3. At any point in time, is there inter-site variation in the technology?

4. What causes stoneworkers to alter the way in which they produce a particular artefact type?

5. Are the various backed blade producing technologies sufficiently restricted in time and distinctive enough to be employed as a means of dating open sites?

Alternatively, the production of backed blades may remain relatively constant through time, with changes in the other aspects of stoneworking contributing to the variation in assemblage composition that was identified in the attribute analysis. This possibility will need to be investigated by more detalled technological analyses than have been presented above.

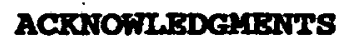

This research was supported by a grant from the Australian Research Council (Grant No. A58715922 - The Moreton Region Archaeological Project - Stage II). Thanks also to Ian MCNiven for artefact illustration. 
Table 1. Numbers of artefacts $>5 \mathrm{~mm}$ in KB:A70.

\begin{tabular}{|c|c|c|c|c|c|c|c|c|}
\hline su & Flakes & $\begin{array}{l}\text { Retouched } \\
\text { Flakes }\end{array}$ & Cores & $\begin{array}{l}\text { Flaked } \\
\text { Pieces }\end{array}$ & $\begin{array}{l}\text { Eraillure } \\
\text { Flakes }\end{array}$ & GS & Axe & TOTAL \\
\hline $\begin{array}{l}1 \\
2 \\
3 \\
4 \\
5 \\
6 \\
7\end{array}$ & $\begin{array}{r}174 \\
108 \\
21 \\
98 \\
81 \\
591 \\
161\end{array}$ & $\begin{array}{r}18 \\
12 \\
1 \\
6 \\
3 \\
30 \\
8\end{array}$ & $\begin{array}{r}13 \\
1 \\
0 \\
6 \\
5 \\
10 \\
1\end{array}$ & $\begin{array}{r}19 \\
11 \\
2 \\
7 \\
12 \\
31 \\
10\end{array}$ & $\begin{array}{l}0 \\
1 \\
0 \\
0 \\
1 \\
0 \\
4\end{array}$ & $\begin{array}{l}0 \\
0 \\
2 \\
0 \\
0 \\
0 \\
1\end{array}$ & $\begin{array}{l}1 \\
0 \\
0 \\
0 \\
1 \\
0 \\
0\end{array}$ & $\begin{array}{r}225 \\
133 \\
26 \\
117 \\
103 \\
662 \\
185\end{array}$ \\
\hline $\begin{array}{r}8 \\
9 \\
10 \\
11 \\
12\end{array}$ & $\begin{array}{r}49 \\
139 \\
26 \\
18 \\
7\end{array}$ & $\begin{array}{r}6 \\
10 \\
3 \\
1 \\
0\end{array}$ & $\begin{array}{l}0 \\
6 \\
1 \\
1 \\
0\end{array}$ & $\begin{array}{l}1 \\
7 \\
0 \\
2 \\
0\end{array}$ & $\begin{array}{l}0 \\
0 \\
0 \\
0 \\
0\end{array}$ & $\begin{array}{l}0 \\
0 \\
0 \\
0 \\
0\end{array}$ & $\begin{array}{l}0 \\
0 \\
0 \\
0 \\
0\end{array}$ & $\begin{array}{r}56 \\
162 \\
30 \\
22 \\
7\end{array}$ \\
\hline Total & 1473 & 98 & 44 & 102 & 6 & 3 & 2 & 1728 \\
\hline
\end{tabular}

SU= Stratigraphic Unit GS = Grindatone

su8-12 are of inixed stratigraphic provenance

Table 2. Number of of artefacts $>5 \mathrm{~mm}$ by raw material in KB:A70.

su Chert. Mudstone Quartzite silcrete Basalt quartz sw other

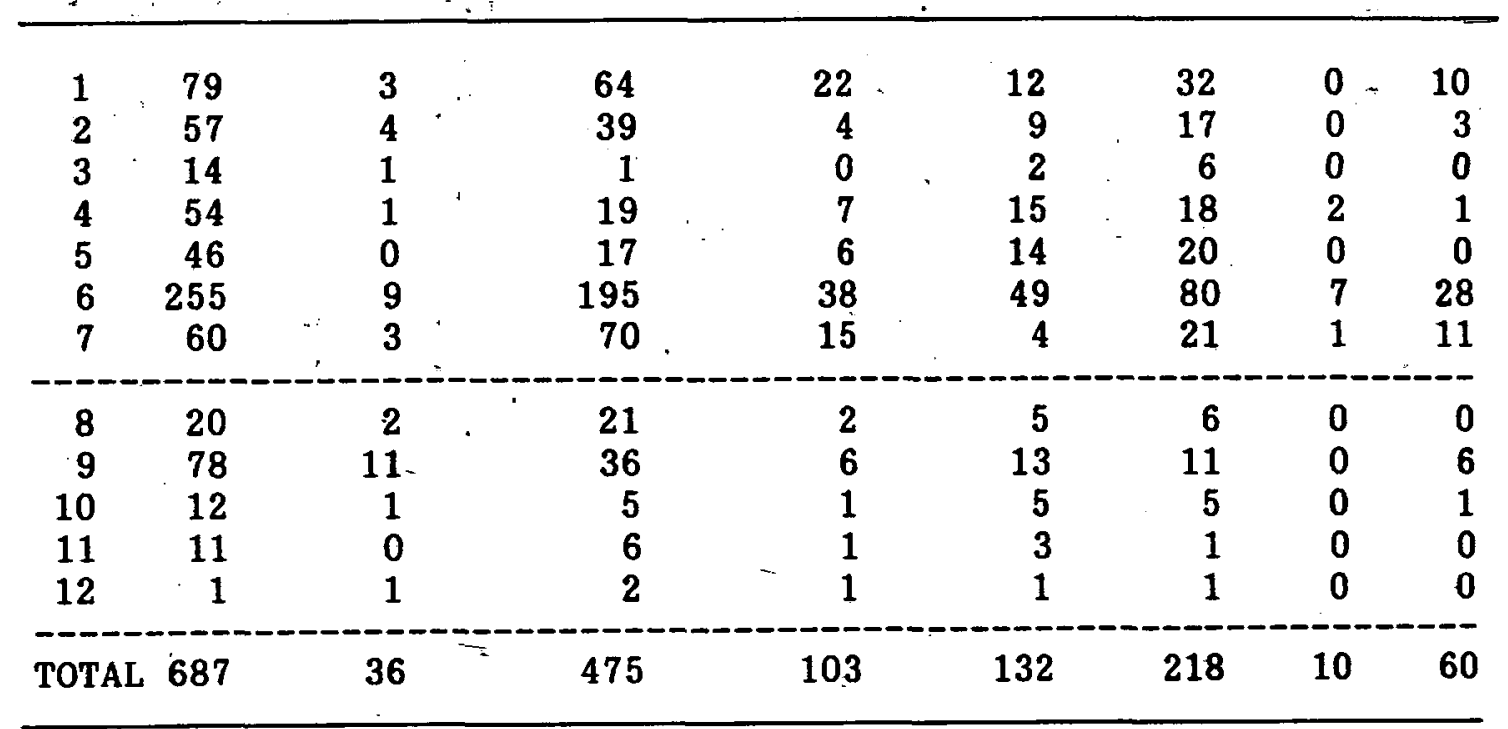

SU $=$ stratigraphic Unit

SW = Silicified wood

su8-12 are of mixed provenance. 
Table 3. Size of complete unretouched flakes $>5 \mathrm{~mm}$ in su6.

\begin{tabular}{|c|c|c|c|c|c|c|}
\hline Variable & Measure & Chert & Quartzite & silcrete & Basalt & Quartz \\
\hline $\begin{array}{l}\text { WEIGHT } \\
(\mathrm{gm})\end{array}$ & $\begin{array}{l}\text { Mean } \\
\text { Std dev. } \\
\text { Minimum } \\
\text { Maximum }\end{array}$ & $\begin{array}{c}2.33 \\
4.14 \\
0.1 \\
27.2\end{array}$ & $\begin{array}{l}1.72 \\
3.20 \\
0.1 \\
24.2\end{array}$ & $\begin{array}{c}2.68 \\
4.12 \\
0.2 \\
17.8\end{array}$ & $\begin{array}{c}1.68 \\
2.45 \\
0.1 \\
12.5\end{array}$ & $\begin{array}{l}0.99 \\
1.11 \\
0.1 \\
5.3\end{array}$ \\
\hline $\begin{array}{l}\text { LENGTH } \\
(\mathrm{cm})\end{array}$ & $\begin{array}{l}\text { Mean } \\
\text { Std dev. } \\
\text { Minimum } \\
\text { Maximum }\end{array}$ & $\begin{array}{l}1.73 \\
0.89 \\
0.5 \\
4.7\end{array}$ & $\begin{array}{l}1.56 \\
0.69 \\
0.6 \\
3.4\end{array}$ & $\begin{array}{l}1.89 \\
0.99 \\
0.7 \\
4.6\end{array}$ & $\begin{array}{l}1.66 \\
0.67 \\
0.5 \\
2.9\end{array}$ & $\begin{array}{l}1.42 \\
0.52 \\
0.8 \\
2.7\end{array}$ \\
\hline $\begin{array}{r}\text { WIDTH } \\
(\mathrm{cm})\end{array}$ & $\begin{array}{l}\text { Mean } \\
\text { Std dev. } \\
\text { Minimum } \\
\text { Maximum }\end{array}$ & $\begin{array}{l}1.47 \\
0.73 \\
0.3 \\
4.8\end{array}$ & $\begin{array}{l}1.38 \\
0.71 \\
0.5 \\
4.5\end{array}$ & $\begin{array}{l}1.60 \\
0.59 \\
1.0 \\
3.1\end{array}$ & $\begin{array}{l}1.54 \\
0.70 \\
0.6 \\
4.1\end{array}$ & $\begin{array}{l}1.11 \\
0.48 \\
0.2 \\
2.2\end{array}$ \\
\hline $\begin{array}{l}\text { THICKNESS } \\
(\mathrm{cm})\end{array}$ & $\begin{array}{l}\text { Mean } \\
\text { Std dev. } \\
\text { Minimum } \\
\text { Maximum }\end{array}$ & $\begin{array}{l}0.39 \\
0.25 \\
0.1 \\
1.4\end{array}$ & $\begin{array}{l}0.36 \\
0.23 \\
0.1 \\
1.3\end{array}$ & $\begin{array}{l}0.40 \\
0.19 \\
0.2 \\
0.9\end{array}$ & $\begin{array}{l}0.34 \\
0.19 \\
0.1 \\
0.8\end{array}$ & $\begin{array}{l}0.36 \\
0.18 \\
0.2 \\
1.1\end{array}$ \\
\hline $\begin{array}{c}\text { VENTRAL } \\
\text { AREA } \\
\left(\mathrm{cm}^{2}\right)\end{array}$ & $\begin{array}{l}\text { Mean } \\
\text { Std dev. } \\
\text { Minimum } \\
\text { Maximum }\end{array}$ & $\begin{array}{c}2.86 \\
2.85 \\
0.30 \\
17.20\end{array}$ & $\begin{array}{r}2.42 \\
2.42 \\
0.63 \\
14.40\end{array}$ & $\begin{array}{r}3.47 \\
3.27 \\
1.00 \\
14.26\end{array}$ & $\begin{array}{c}2.79 \\
2.35 \\
0.55 \\
11.89\end{array}$ & $\begin{array}{l}1.64 \\
1.08 \\
0.24 \\
4.05\end{array}$ \\
\hline & $N=$ & 158 & 108 & 18 & 27 & 42 \\
\hline
\end{tabular}

Table 4. Platform size of complete unretouched flakes $>5 \mathrm{~mm}$ in sU6.

\begin{tabular}{clccccc}
\hline Variable & Measure & Chert & Quartzite & Silcrete & Basalt & Quartz \\
\hline PLATFORM & Mean & 0.97 & 0.90 & 0.94 & 0.93 & 0.73 \\
WIDTH & Std dev. & 0.61 & 0.57 & 0.54 & 0.70 & 0.45 \\
(cm) & Minimum & 0.2 & 0.1 & 0.3 & 0.3 & 0.1 \\
& Maximum & 3.6 & 3.2 & 2.3 & 3.6 & 2.2 \\
& & & & & & \\
PLATFORM & Mean & 0.29 & 0.28 & 0.30 & 0.25 & 0.25 \\
THICKNESS & Std dev. & 0.21 & 0.20 & 0.22 & 0.19 & 0.17 \\
(cm) & Minimum & 0.1 & 0.1 & 0.1 & 0.1 & 0.1 \\
& Maximum & 1.3 & 1.1 & 0.9 & 0.7 & 0.6 \\
PLATFORM & Mean & 0.37 & 0.34 & 0.34 & 0.32 & 0.23 \\
AREA & Std dev. & 0.53 & 0.52 & 0.35 & 0.51 & 0.27 \\
(cm ${ }^{2}$ ) & Minimum & 0.02 & 0.01 & 0.03 & 0.03 & 0.01 \\
& Maximum & 4.16 & 2.88 & 1.15 & 2.52. & 1.32 \\
& & & & & & 38 \\
& N & 149 & 104 & 18 & 26 & 38 \\
& & & & &. .2 & \\
\hline
\end{tabular}


Table 5. Shape of complete unretouched flakes $>5 \mathrm{~mm}$ in su6.

\begin{tabular}{|c|c|c|c|c|c|c|}
\hline Variable & Meadure & Chert & Quartite & silereto & Babait & Quartz \\
\hline ELONGATION & $\begin{array}{l}\text { Mean } \\
\text { Std dev. } \\
\text { Minimun } \\
\text { Maximum } \\
z \text { L }>2 W \\
N\end{array}$ & $\begin{array}{c}1.36 \\
0.83 \\
0.31 \\
5.22 \\
17.1 \\
158\end{array}$ & $\begin{array}{r}1.28 \\
0.68 \\
0.43 \\
4.80 \\
12.1 \\
108\end{array}$ & $\begin{array}{l}1.17 \\
0.39 \\
0.47 \\
2.07 \\
5.6 \\
18\end{array}$ & $\begin{array}{l}1.19 \\
0.60 \\
0.37 \\
3.00 \\
11.1 \\
27\end{array}$ & $\begin{array}{l}1.54 \\
0.98 \\
0.48 \\
6.00 \\
21.5 \\
42\end{array}$ \\
\hline $\begin{array}{l}\text { PARALLEL - } \\
\text { INDEX }\end{array}$ & $\begin{array}{l}\text { Mean } \\
\text { Std dev. } \\
\text { Minimum } \\
\text { Maximum } \\
x<1.0 \\
x<2.0 \\
N\end{array}$ & $\begin{array}{c}1.90 \\
1.17 \\
0.69 \\
7.00 \\
9.4 \\
68.5 \\
149\end{array}$ & $\begin{array}{c}1.92 \\
1.17 \\
0.75 \\
6.14 \\
9.6 \\
65.4 \\
104\end{array}$ & $\begin{array}{l}2.06 \\
1.00 \\
0.79 \\
4.67 \\
5.6 \\
55.6 \\
18\end{array}$ & $\begin{array}{l}2.11 \\
1.07 \\
0.67 \\
5.00 \\
7.7 \\
50.0 \\
26\end{array}$ & $\begin{array}{l}2.13 \\
1.64 \\
0.22 \\
8.00 \\
10.5 \\
63.2 \\
38\end{array}$ \\
\hline $\begin{array}{l}\text { RELATIVE } \\
\text { THICKNESS } \\
\text { INDEX }\end{array}$ & $\begin{array}{l}\text { Mean } \\
\text { Std dev. } \\
\text { Minimum } \\
\text { Maximum } \\
\text { N }\end{array}$ & $\begin{array}{r}4.65 \\
2.61 \\
0.75 \\
19.00 \\
158\end{array}$ & $\begin{array}{r}4.53 \\
2.38 \\
1.43 \\
14.33 \\
108\end{array}$ & $\begin{array}{l}4.36 \\
1.35 \\
2.00 \\
7.50 \\
18\end{array}$ & $\begin{array}{r}5.50 \\
2.59 \\
2.00 \\
11.00 \\
27\end{array}$ & $\begin{array}{l}3.59 \\
2.10 \\
0.50 \\
10.50 \\
42\end{array}$ \\
\hline LT INDEX & $\begin{array}{l}\text { Mean } \\
\text { Stdi dev. } \\
\text { Minimum } \\
\text { Maximum } \\
\mathbf{x}<1.0 \\
\mathbb{N}\end{array}$ & $\begin{array}{c}1.63 \\
0.99 \\
0.33 \\
6.00 \\
20.1 \\
149\end{array}$ & $\begin{array}{c}1.55 \\
0.82 \\
0.50 \\
4.00 \\
13.5 \\
104\end{array}$ & $\begin{array}{l}1.79 \\
1.06 \\
0.67 \\
4.00 \\
22.2 \\
18\end{array}$ & $\begin{array}{l}1.76 \\
1.24 \\
0.40 \\
6.00 \\
15.4 \\
26\end{array}$ & $\begin{array}{l}1.95 \\
1.25 \\
0.40 \\
.6 .00 \\
10.5 \\
38\end{array}$ \\
\hline $\begin{array}{l}\text { PLATFORM } \\
\text { THICKNESS } \\
\text { INDEX }\end{array}$ & $\begin{array}{l}\text { Mean } \\
\text { Std dev. } \\
\text { Minimum } \\
\text { Maximum } \\
\text { N }\end{array}$ & $\begin{array}{r}3.98 \\
2.29 \\
0.67 \\
13.00 \\
144\end{array}$ & $\begin{array}{r}3.62 \\
1.73 \\
1.00 \\
11.00 \\
104\end{array}$ & $\begin{array}{r}3.79 \\
1.66 \\
1.00 \\
7.00 \\
18\end{array}$ & $\begin{array}{r}4.29 \\
2.00 \\
1.33 \\
9.00 \\
26\end{array}$ & $\begin{array}{l}3.51 \\
2.57 \\
1.00 \\
16.00 \\
38\end{array}$ \\
\hline $\begin{array}{l}\text { INDEX OF } \\
\text { CROSS- } \\
\text { SECTIONAL } \\
\text { AREA }\end{array}$ & $\begin{array}{l}\text { Mean } \\
\text { Std dev. } \\
\text { Minimum } \\
\text { Maximum } \\
\mathbf{x}<1.0 \\
\mathbf{N}\end{array}$ & $\begin{array}{r}3.32 \\
3.08 \\
0.34 \\
16.67 \\
18.8 \\
149\end{array}$ & $\begin{array}{c}3.42 \\
3.61 \\
0.50 \\
17.33 \\
16.4 \\
104\end{array}$ & $\begin{array}{l}4.34 \\
4.14 \\
0.53 \\
14.00 \\
16.7 \\
18\end{array}$ & $\begin{array}{l}4.25 \\
4.49 \\
0.49 \\
20.00 \\
15.4 \\
26\end{array}$ & $\begin{array}{l}4.93 \\
5.59 \\
0.30 \\
23.59 \\
18.4 \\
38 .\end{array}$ \\
\hline
\end{tabular}

Table 6. Size of complete unretouched flakes $>5 \mathrm{~mm}$ in $503-5$.

\begin{tabular}{|c|c|c|c|c|c|c|}
\hline varlable & Measure & & Chert & Quartzite & Basalt & Quartz \\
\hline $\begin{array}{c}\text { WEIGHT } \\
\text { (g⿴囗十) } \\
.\end{array}$ & $\begin{array}{l}\text { Mean } \\
\text { Std dev. } \\
\text { Minimum } \\
\text { Maximus }\end{array}$ & $\because$ & $\begin{array}{c}1.97 \\
3.89 \\
0.1 \\
24.3\end{array}$ & $\begin{array}{c}2.14 \\
3.28 \\
0.1 \\
13.5\end{array}$ & $\begin{array}{l}3.51 \\
4.58 \\
0.1 \\
18.6\end{array}$ & $\begin{array}{l}1.17 \\
1.31 \\
0.1 \\
6.0\end{array}$ \\
\hline $\begin{array}{l}\text { LENGTH } \\
(\mathrm{cm})\end{array}$ & $\begin{array}{l}\text { Mean } \\
\text { Std dev. } \\
\text { Miniaun } \\
\text { Maxịun }\end{array}$ & & $\begin{array}{l}1.76 \\
0.85 \\
0.6 \\
4.7\end{array}$ & $\begin{array}{l}1.84 \\
0.93 \\
0.7 \\
4.8\end{array}$ & $\begin{array}{l}2.19 \\
1.03 \\
0.8 \\
5.0\end{array}$ & $\begin{array}{l}1.52 \\
0.57 \\
0.7 \\
3.0\end{array}$ \\
\hline $\begin{array}{r}\text { WI DTH } \\
(\mathrm{cm})\end{array}$ & $\begin{array}{l}\text { Mean } \\
\text { Std dev. } \\
\text { Mininum } \\
\text { Maximun }\end{array}$ & & $\begin{array}{l}1.37 \\
0.61 \\
0.4 \\
3.3\end{array}$ & $\begin{array}{l}1.49 \\
0.77 \\
0.7 \\
4.0\end{array}$ & $\begin{array}{l}1.93 \\
1.03 \\
0.7 \\
5.4\end{array}$ & $\begin{array}{l}1.20 \\
0.51 \\
0.6 \\
2.3\end{array}$ \\
\hline $\begin{array}{l}\text { THICRNESS } \\
\text { (cm) }\end{array}$ & $\begin{array}{l}\text { Mean } \\
\text { Std dev. } \\
\text { Minimum } \\
\text { Maxinum }\end{array}$ & & $\begin{array}{l}0.33 \\
0.24 \\
0.1 \\
1.6\end{array}$ & $\begin{array}{l}0.37 \\
0.22 \\
0.1 \\
1.0\end{array}$ & $\begin{array}{l}0.43 \\
0.21 \\
0.1 \\
1.1\end{array}$ & $\begin{array}{l}0.35 \\
0.17 \\
0.2 \\
0.8\end{array}$ \\
\hline $\begin{array}{c}\text { VENTBAL } \\
\text { AREA } \\
\left(\mathrm{CI}^{2}\right)\end{array}$ & $\begin{array}{l}\text { Mean } \\
\text { Std dev. } \\
\text { Mininum } \\
\text { Maxi muw }\end{array}$ & & $\begin{array}{r}2.66 \\
2.43 \\
0.52 \\
12.16\end{array}$ & $\begin{array}{r}3.06 \\
2.90 \\
0.49 \\
12.40\end{array}$ & $\begin{array}{c}4.53 \\
3.82 \\
0.90 \\
15.5\end{array}$ & $\begin{array}{l}1.95 \\
1.37 \\
0.48 \\
6.30\end{array}$ \\
\hline , & $\mathbf{N}$ & & 53 & 36 & 22 & 25 \\
\hline
\end{tabular}


Table 7. Platform size of complete unretouched flakes $>5 \mathrm{~mm}$ in su3-5.

\begin{tabular}{clllll}
\hline Variable & Measure & Chert & Quartzite & Basalt & Quartz \\
& & & & & \\
PLATFORM & Mean & 0.87 & 0.89 & 1.32 & 0.79 \\
WIDTH & Std dev. & 0.55 & 0.49 & 0.89 & 0.43 \\
(cm) & Minimum & 0.2 & 0.2 & 0.3 & 0.2 \\
& Maximum & 2.4 & 2.0 & 3.8 & 1.6 \\
PLATFORM & Mean & 0.26 & 0.29 & 0.37 & 0.27 \\
THICKNESS & Std dev. & 0.24 & 0.20 & 0.25 & 0.16 \\
(cm) & Minimum & 0.1 & 0.1 & 0.1 & 0.1 \\
& Maximum & 1.2 & 0.8 & 1.1 & 0.6 \\
PLATFORM & Mean & 0.32 & 0.31 & 0.64 & 0.27 \\
AREA & Std dev. & 0.56 & 0.34 & 0.81 & 0.26 \\
(cm ${ }^{2}$ ) & Minimum & 0.02 & 0.02 & 0.03 & 0.02 \\
& Maximum & 2.64 & 1.40 & 0.81 & 0.26 \\
& & & & & \\
& N & 49 & 34 & 22 & 23 \\
\hline
\end{tabular}

Table 8. Shape of complete unretouched flakes $>5 \mathrm{~mm}$ in s03-5.

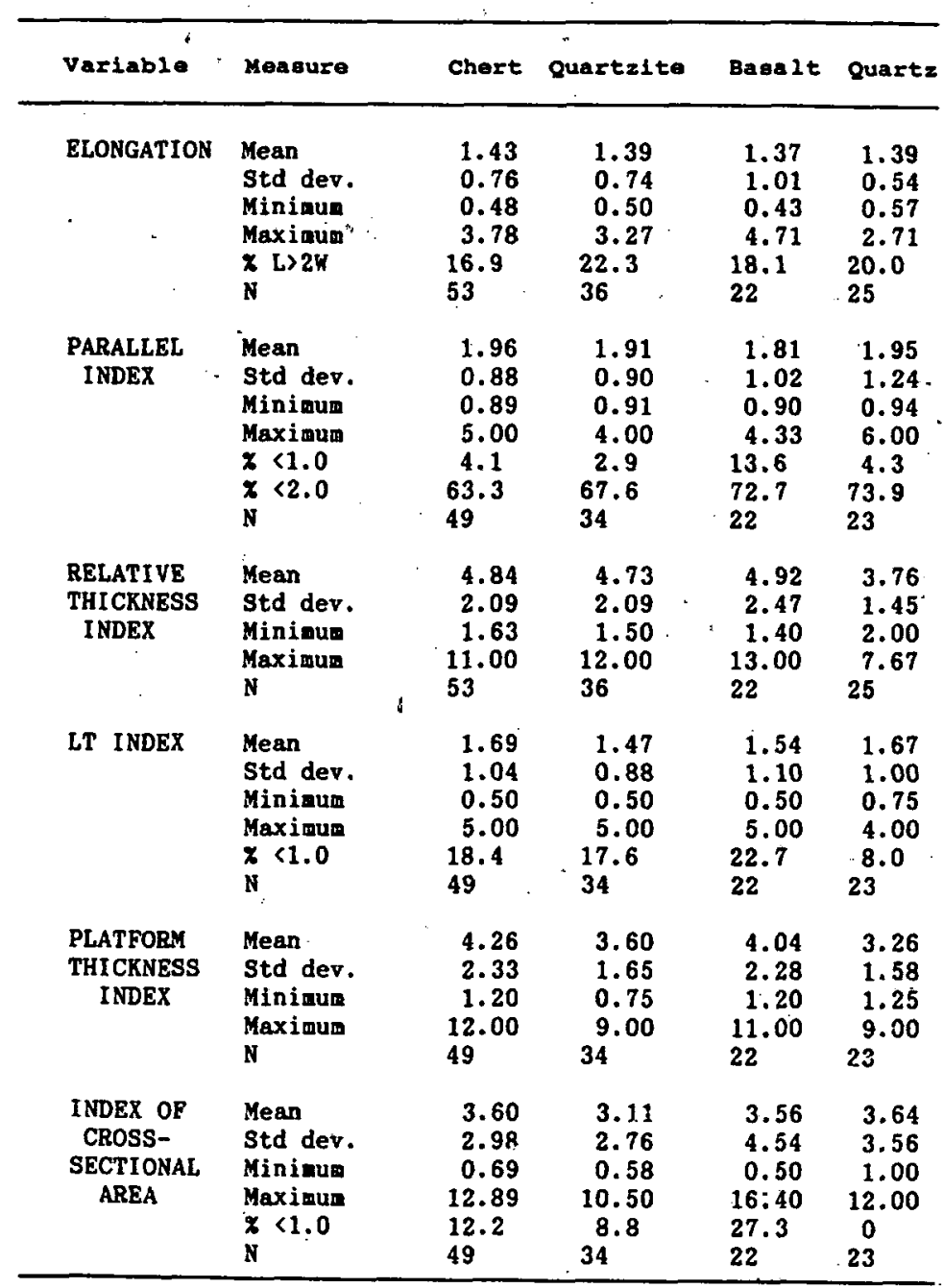


Table 9. Technological attributes of complete unretouched fiakes $>5 \mathrm{~mm}$ in su6.

\begin{tabular}{|c|c|c|c|c|c|c|c|}
\hline $\begin{array}{l}\text { Aspect of } \\
\text { Technology }\end{array}$ & Trait & Measure & Chert & Quartzite & Silcrete & Basalt & Quartz \\
\hline CORE SHAPE & $\begin{array}{l}\text { Platform } \\
\text { angles }\end{array}$ & $\begin{array}{l}\text { \% flakes }<70^{\circ} \\
\text { mode }\end{array}$ & $\begin{array}{c}52.3 \\
60-70^{\circ}\end{array}$ & $\begin{array}{c}47.4 \\
70-79^{\circ}\end{array}$ & $\begin{array}{c}53.3 \\
60-69^{\circ}\end{array}$ & $\begin{array}{c}55.0 \\
60-69^{\circ}\end{array}$ & $\begin{array}{c}28.6 \\
70-79^{\circ}\end{array}$ \\
\hline $\begin{array}{l}\text { PRECISION } \\
\text { OF BLOW }\end{array}$ & $\begin{array}{l}\text { Platform } \\
\text { size }\end{array}$ & $\begin{array}{l}\text { \% shattered } \\
\text { \% focalized } \\
\text { \% wide/bending }\end{array}$ & $\begin{array}{r}14.6 \\
9.5 \\
75.3\end{array}$ & $\begin{array}{r}14.8 \\
9.3 \\
74.1\end{array}$ & $\begin{array}{r}5.6 \\
16.7 \\
77.8\end{array}$ & $\begin{array}{r}22.2 \\
7.4 \\
70.4\end{array}$ & $\begin{array}{r}33.3 \\
2.4 \\
64.3\end{array}$ \\
\hline $\begin{array}{l}\text { PLATFORM } \\
\text { PREPARATION }\end{array}$ & $\begin{array}{l}\text { Platform } \\
\text { surface }\end{array}$ & $\begin{array}{l}\text { \% cortex } \\
\text { \% shattered } \\
\text { * single scar } \\
\text { \% several scars } \\
\text { \% faceting }\end{array}$ & $\begin{array}{r}15.8 \\
14.6 \\
47.5 \\
15.2 \\
6.3\end{array}$ & $\begin{array}{r}11.1 \\
15.7 \\
58.3 \\
12.0 \\
1.9\end{array}$ & $\begin{array}{r}22.2 \\
5.6 \\
55.6 \\
11.1 \\
5.6\end{array}$ & $\begin{array}{r}18.5 \\
22.2 \\
29.6 \\
22.2 \\
7.4\end{array}$ & $\begin{array}{l}31.0 \\
33.3 \\
31.0 \\
0 \\
0\end{array}$ \\
\hline $\begin{array}{l}\text { OVERHANG } \\
\text { REMOVAL }\end{array}$ & $\begin{array}{l}\text { Overhang } \\
\text { removal }\end{array}$ & $\begin{array}{l}\text { \% flakes with } \\
\text { overhang removed }\end{array}$ & 13.3 & 13.0 & 11.1 & 11.1 & 0 \\
\hline $\begin{array}{l}\text { APPLIED } \\
\text { FORCE }\end{array}$ & Termination & $\begin{array}{l}\text { \% feather } \\
\text { x hinge } \\
\text { \% step } \\
\text { \% outrepasse } \\
\text { ratio hinge:step }\end{array}$ & $\begin{array}{r}72.8 \\
18.4 \\
8.2 \\
0.6 \\
2.2: 1\end{array}$ & $\begin{array}{r}64.8 \\
3.7 \\
31.5 \\
0 \\
0.1: 1\end{array}$ & $\begin{array}{r}66.7 \\
5.6 \\
27.8 \\
0 \\
0.2: 1\end{array}$ & $\begin{array}{l}77.8 \\
14.8 \\
7.4 \\
0 \\
2.0: 1\end{array}$ & $\begin{array}{r}73.8 \\
4.8 \\
21.4 \\
0 . \\
0.2: 1\end{array}$ \\
\hline DECORT ICATION & $\begin{array}{l}\text { Amount of } \\
\text { Cortex }\end{array}$ & $\begin{array}{l}\text { \% flakes with } \\
\text { cortex } \\
\text { \% flakes with } \\
>50 \% \text { cortex }\end{array}$ & $\begin{array}{l}39.9 \\
11.4\end{array}$ & $\begin{array}{r}27.8 \\
6.4\end{array}$ & $\begin{array}{l}.61 .1 \\
27.8\end{array}$ & $\begin{array}{l}25.9 \\
11.1\end{array}$ & $\begin{array}{l}23.8 \\
4.8\end{array}$ \\
\hline $\mathbf{N}$ & & & 158 & 108 & 18 & 27 & 42 \\
\hline
\end{tabular}

Table 10. Technological attributes of complete unretouched flakes $>5 \mathrm{~mm}$ in su3-5.

\begin{tabular}{|c|c|c|c|c|c|c|}
\hline $\begin{array}{l}\text { Aspect of } \\
\text { Technology }\end{array}$ & Trait & Measure : & Chert & Quartzite & Basalt & Quartz \\
\hline CORE SHAPE & $\begin{array}{l}\text { Plat fora } \\
\text { angles }\end{array}$ & $\begin{array}{l}\% \text { f lakes }<70^{\circ} \\
\text { mode. }\end{array}$ & $\begin{array}{c}43.9 \\
70-79^{\circ}\end{array}$ & $\begin{array}{c}27.8 \\
80-89^{\circ}\end{array}$ & $\begin{array}{c}59.1 \\
60-69^{\circ}\end{array}$ & $\begin{array}{c}24.0 \\
70-79^{\circ}\end{array}$ \\
\hline $\begin{array}{l}\text { PRECISION } \\
\text { OF BLOH }\end{array}$ & $\begin{array}{l}\text { Platform } \\
\text { size }\end{array}$ & $\begin{array}{l}\text { \% shattered } \\
\text { z focalized } \\
\text { z wide/bending }\end{array}$ & $\begin{array}{l}18.9 \\
15.1 \\
64.2\end{array}$ & $\begin{array}{r}8.3 \\
8.3 \\
80.6\end{array}$ & $\begin{array}{r}9.1 \\
4.5 \\
.86 .4\end{array}$ & $\begin{array}{l}16.0 \\
16.0 \\
68.0\end{array}$ \\
\hline $\begin{array}{l}\text { PLATFORM } \\
\text { PREPARATION }\end{array}$ & $\begin{array}{l}\text { Platform } \\
\text { surface }\end{array}$ & $\begin{array}{l}\text { \% cortex } \\
\text { \% shattered } \\
\text { \% single scar } \\
\text { \% several scars } \\
\text { \% faceting }\end{array}$ & $\begin{array}{r}11.3 \\
18.9 \\
45.3 \\
7.5 \\
15.1\end{array}$ & $\begin{array}{l}0 \\
8.3 \\
47.2 \\
19.4 \\
22.2\end{array}$ & $\begin{array}{r}27.3 \\
9.1 \\
36.4 \\
18.2 \\
4.5\end{array}$ & $\begin{array}{l}20.0 \\
20.0 \\
40.0 \\
20.0 \\
0\end{array}$ \\
\hline $\begin{array}{l}\text { OVERHANG } \\
\text { REMOVAL }\end{array}$ & $\begin{array}{l}\text { Overhang } \\
\text { removal }\end{array}$ & $\begin{array}{l}\text { \& flakes with } \\
\text { overhang removed }\end{array}$ & 11.3 & 8.3 & 4.5 & 0 \\
\hline $\begin{array}{l}\text { APPLIED } \\
\text { FORCE }\end{array}$ & Termination & $\begin{array}{l}\text { \% feather } \\
\text { \% hinge } \\
\text { \% step } \\
\text { \% outrepasse } \\
\text { ratio hinge: step }\end{array}$ & $\begin{array}{r}67.9 \\
9.4 \\
17.0 \\
5.7 \\
0.6: 1\end{array}$ & $\begin{array}{r}63.9 \\
5.6 \\
30.6 \\
0 \\
0.2: 1\end{array}$ & $\begin{array}{c}85.7 \\
0 \\
14.3 \\
0 \\
--\end{array}$ & $\begin{array}{c}79.2 \\
4.2 \\
16.7 \\
0 \\
0.3: 1\end{array}$ \\
\hline DECORTICATION & $\begin{array}{l}\text { Amount of } \\
\text { Cortex }\end{array}$ & $\begin{array}{l}\text { \% flakes with } \\
\text { cortex } \\
\% \text { flakes with } \\
>50 x \text { cortex }\end{array}$ & $\begin{array}{l}35.8 \\
13.3\end{array}$ & $\begin{array}{r}22.2 \\
5.6\end{array}$ & $\begin{array}{r}22.7 \\
4.5\end{array}$ & $\begin{array}{l}28.0 \\
8.0\end{array}$ \\
\hline $\mathbf{N}$ & & & 53 & 36 & 22 & 25 \\
\hline
\end{tabular}


Table 11. Size of complete unretouched chert flakes >5mn in KB:A70.

\begin{tabular}{|c|c|c|c|c|c|c|}
\hline \multirow[b]{2}{*}{ Variable } & \multirow[b]{2}{*}{ Measure } & \multicolumn{3}{|c|}{ STRATIGRAPHIC } & \multicolumn{2}{|l|}{ UNIT } \\
\hline & & 1 & 2 & $3-5$ & 6 & 7 \\
\hline $\begin{array}{l}\text { WEIGHT } \\
\text { (gm) }\end{array}$ & $\begin{array}{l}\text { Mean } \\
\text { Std dev. } \\
\text { Minimum } \\
\text { Maximum } \\
\mathrm{N}\end{array}$ & $\begin{array}{l}2.79 \\
2.98 \\
0.1 \\
11.7 \\
38\end{array}$ & $\begin{array}{l}2.69 \\
8.04 \\
0.2 \\
45.0 \\
31\end{array}$ & $\begin{array}{l}1.97 \\
3.89 \\
0.1 \\
24.3 \\
53\end{array}$ & $\begin{array}{r}2.33 \\
4.14 \\
0.1 \\
27.2 \\
158\end{array}$ & $\begin{array}{l}2.49 \\
4.17 \\
0.1 \\
18.6 \\
36\end{array}$ \\
\hline $\begin{array}{l}\text { LENGTH } \\
(\mathrm{cm})\end{array}$ & $\begin{array}{l}\text { Mean } \\
\text { Std dev. } \\
\text { Minimum } \\
\text { Maximum } \\
\mathrm{N}\end{array}$ & $\begin{array}{l}1.86 \\
0.67 \\
0.8 \\
3.3 \\
44\end{array}$ & $\begin{array}{l}1.85 \\
1.00 \\
0.5 \\
5.4 \\
35\end{array}$ & $\begin{array}{l}1.70 \\
0.80 \\
0.6 \\
4.7 \\
67\end{array}$ & $\begin{array}{c}1.71 \\
0.87 \\
0.5 \\
4.7 \\
176\end{array}$ & $\begin{array}{l}1.64 \\
0.80 \\
0.6 \\
4.0 \\
37\end{array}$ \\
\hline $\begin{array}{c}\text { WIDTH } \\
(\mathrm{cm})\end{array}$ & $\begin{array}{l}\text { Mean } \\
\text { Std dev. } \\
\text { Minimum } \\
\text { Maximum } \\
\mathrm{N}\end{array}$ & $\begin{array}{l}1.68 \\
0.91 \\
0.4 \\
4.3 \\
48\end{array}$ & $\begin{array}{l}1.29 \\
0.68 \\
0.5 \\
3.3 \\
39\end{array}$ & $\begin{array}{l}1.28 \\
0.60 \\
0.3 \\
3.3 \\
86\end{array}$ & $\begin{array}{c}1.37 \\
0.69 \\
0.2 \\
4.8 \\
205\end{array}$ & $\begin{array}{l}1.47 \\
0.72 \\
0.7 \\
4.0 \\
45\end{array}$ \\
\hline $\begin{array}{l}\text { THICKNESS } \\
\text { (cm) }\end{array}$ & $\begin{array}{l}\text { Mean } \\
\text { Std dev. } \\
\text { Minimum } \\
\text { Maximum } \\
\text { N }\end{array}$ & $\begin{array}{l}0.44 \\
0.27 \\
0.1 \\
1.5 \\
56\end{array}$ & $\begin{array}{l}0.37 \\
0.32 \\
0.1 \\
2.1 \\
46\end{array}$ & $\begin{array}{r}0.33 \\
0.21 \\
0.1 \\
1.6 \\
105\end{array}$ & $\begin{array}{r}0.37 \\
0.23 \\
0.1 \\
1.4 \\
226\end{array}$ & $\begin{array}{l}0.37 \\
0.23 \\
0.1 \\
1.1 \\
47\end{array}$ \\
\hline $\begin{array}{l}\text { VENTRAI } \\
\text { AREA } \\
\left(\mathrm{cm}^{2}\right)\end{array}$ & $\begin{array}{l}\text { Mean } \\
\text { Std dev. } \\
\text { Minimum } \\
\text { Maximum } \\
\mathrm{N}\end{array}$ & $\begin{array}{l}3.64 \\
2.90 \\
0.44 \\
13.33 \\
38\end{array}$ & $\begin{array}{r}2.69 \\
3.36 \\
0.40 \\
17.82 \\
31\end{array}$ & $\begin{array}{r}2.66 \\
2.43 \\
0.52 \\
12.16 \\
53\end{array}$ & $\begin{array}{r}2.89 \\
2.85 \\
0.30 \\
17.20 \\
158\end{array}$ & $\begin{array}{l}2.94 \\
2.88 \\
0.49 \\
12.92 \\
36\end{array}$ \\
\hline
\end{tabular}

Table 12. Platform size of complete unretouched chert flakes $>5 \mathrm{~mm}$ in $\mathbf{K B}: \mathbf{A 7 0}$.

\begin{tabular}{|c|c|c|c|c|c|c|}
\hline \multirow[b]{2}{*}{ Variable } & \multirow[b]{2}{*}{ Measure } & \multicolumn{5}{|c|}{ STRATIGRAPHIC UNIT } \\
\hline & & 1 & 2 & $3-5$ & 6 & 7 \\
\hline $\begin{array}{l}\text { PLATFORM } \\
\text { WIDTH } \\
\text { (cm) } \\
\text { PLATFORM } \\
\text { THICKNESS } \\
\text { (CM) } \\
\text { PLATFORM } \\
\text { AREA } \\
\left(\mathrm{cm}^{2}\right)\end{array}$ & $\begin{array}{l}\text { Mean } \\
\text { Std dev. } \\
\text { Minimum } \\
\text { Maximum } \\
\text { Mean } \\
\text { Std dev. } \\
\text { Minimum } \\
\text { Maximum } \\
\text { Mean } \\
\text { Std dev. } \\
\text { Minimum } \\
\text { Maximum }\end{array}$ & $\begin{array}{l}1.22 \\
0.81 \\
0.2 \\
3.7 \\
0.30 \\
0.17 \\
0.1 \\
0.8 \\
0.41 \\
0.39 \\
0.02 \\
1.76\end{array}$ & $\begin{array}{l}0.79 \\
0.50 \\
0.2 \\
2.2 \\
0.20 \\
0.14 \\
0.1 \\
0.7 \\
0.19 \\
0.28 \\
0.02 \\
1.54\end{array}$ & $\begin{array}{l}0.86 \\
0.51 \\
0.2 \\
2.4 \\
0.25 \\
0.23 \\
0.1 \\
1.2 \\
0.30 \\
0.52 \\
0.02 \\
2.64\end{array}$ & $\begin{array}{l}0.94 \\
0.60 \\
0.1 \\
3.6 \\
0.29 \\
0.21 \\
0.1 \\
1.3 \\
0.35 \\
0.51 \\
0.01 \\
4.16\end{array}$ & $\begin{array}{l}0.97 \\
0.51 \\
0.2 \\
2.2 \\
0.31 \\
0.19 \\
0.1 \\
1.0 \\
0.36 \\
0.41 \\
0.02 \\
1.80\end{array}$ \\
\hline & $\mathbf{N}$ & 39 & 33 & 59 & 164 & 35 \\
\hline
\end{tabular}


Table 13. Shape of complete unretouched chert flakes $>5 \mathrm{~mm}$ in KB:A70.

\begin{tabular}{|c|c|c|c|c|c|c|}
\hline \multirow[b]{2}{*}{ variable } & \multirow[b]{2}{*}{ Meagure } & \multicolumn{5}{|c|}{ STRATIGRAPHIC UNIT } \\
\hline & & 1 & 2 & $3-5$ & 6 & 7 \\
\hline moNGATIOA & $\begin{array}{l}\text { Kean } \\
\text { Std dev. } \\
\text { Mininuw } \\
\text { Maxinu } \\
x \text { L>2W } \\
N\end{array}$ & $\begin{array}{l}1.21 \\
0.54 \\
0.61 \\
2.75 \\
10.5 \\
38\end{array}$ & $\begin{array}{l}1.54 \\
0.74 \\
0.54 \\
3.80 \\
29.0 \\
31\end{array}$ & $\begin{array}{l}1.43 \\
0.76 \\
0.48 \\
3.78 \\
16.9 \\
53\end{array}$ & $\begin{array}{c}1.36 \\
0.83 \\
0.31 \\
5.22 \\
17.1 \\
149\end{array}$ & $\begin{array}{l}1.15 \\
0.45 \\
0.47 \\
2.13 \\
5.6 \\
36\end{array}$ \\
\hline $\begin{array}{l}\text { PARALLEL } \\
\text { IRDEX }\end{array}$ & $\begin{array}{l}\text { Mean } \\
\text { Std dev. } \\
\text { Miniaus } \\
\text { Maximun } \\
x<1.0 \\
x<2.0 \\
\text { N }\end{array}$ & $\begin{array}{l}2.00 \\
1.30 \\
0.67 \\
6.50 \\
14.7 \\
64.7 \\
34\end{array}$ & $\begin{array}{c}2.24 \\
1.97 \\
0.86 \\
10.50 \\
7.1 \\
57.1 \\
28\end{array}$ & $\begin{array}{l}1.96 \\
0.88 \\
0.89 \\
5.00 \\
4.1 \\
63.3 \\
49\end{array}$ & $\begin{array}{c}1.90 \\
1.17 \\
0.69 \\
7.00 \\
9.4 \\
68.5 \\
149\end{array}$ & $\begin{array}{l}2.04 \\
1.50 \\
0.82 \\
7.33 \\
11.8 \\
70.6 \\
34\end{array}$ \\
\hline $\begin{array}{l}\text { RELATIVE } \\
\text { TEICKANSS } \\
\text { IKDEX }\end{array}$ & $\begin{array}{l}\text { Mean } \\
\text { Std dev. } \\
\text { Mininun } \\
\text { Maximun } \\
\text { N }\end{array}$ & $\begin{array}{r}4.73 \\
2.34 \\
0.93 \\
12.00 \\
38\end{array}$ & $\begin{array}{r}4.74 \\
2.79 \\
1.00 \\
15.00 \\
31\end{array}$ & $\begin{array}{r}4.84 \\
2.09 \\
1.63 \\
11.00 \\
53\end{array}$ & $\begin{array}{r}4.65 \\
2.61 \\
0.75 \\
19.00 \\
158\end{array}$ & $\begin{array}{r}4.40 \\
2.06 \\
1.86 \\
13.00 \\
36\end{array}$ \\
\hline IT INDEX & $\begin{array}{l}\text { Mean } \\
\text { Std dev. } \\
\text { Mininua } \\
\text { Maxiaun } \\
\text { X }<1.0 \\
\text { N }\end{array}$ & $\begin{array}{l}1.79 \\
1.29 \\
0.63 \\
8.00 \\
8.8 \\
34\end{array}$ & $\begin{array}{l}1.93 \\
1.61 \\
0.40 \\
7.00 \\
17.9 \\
28\end{array}$ & $\begin{array}{l}1.69 \\
1.04 \\
0.50 \\
5.00 \\
18.4 \\
49\end{array}$ & $\begin{array}{c}1.63 \\
0.99 \\
0.33 \\
6.00 \\
20.1 \\
149\end{array}$ & $\begin{array}{l}1.52 \\
0.88 \\
0.50 \\
5.00 \\
17.6 \\
34\end{array}$ \\
\hline $\begin{array}{l}\text { PLATFORY } \\
\text { THICKONESS } \\
\text { INDEX }\end{array}$ & $\begin{array}{l}\text { Mean } \\
\text { Std dev. } \\
\text { Minimum } \\
\text { Maxinua } \\
\text { N }\end{array}$ & $\begin{array}{l}5.13 \\
6.32 \\
1.00 \\
37.00 \\
34\end{array}$ & $\begin{array}{r}4.40 \\
3.06 \\
1.00 \\
14.00 \\
28\end{array}$ & $\begin{array}{l}4.26 \\
2.33 \\
1.20 \\
12.00 \\
49\end{array}$ & $\begin{array}{r}3.98 \\
2.29 \\
0.67 \\
13.00 \\
149\end{array}$ & $\begin{array}{r}3.60 \\
2.03 \\
1.00 \\
11.00 \\
34\end{array}$ \\
\hline $\begin{array}{l}\text { INDEX OF } \\
\text { CROSS- } \\
\text { SECT IONAL } \\
\text { AREA }\end{array}$ & $\begin{array}{l}\text { Mean } \\
\text { Std dev. } \\
\text { Mininum } \\
\text { Maxinum } \\
x<1.0 \\
N\end{array}$ & $\begin{array}{l}3.51 \\
2.91 \\
0.44 \\
14.25 \\
11.8 \\
34\end{array}$ & $\begin{array}{r}6.05 \\
13.66 \\
0.58 \\
73.50 \\
14.3 \\
28\end{array}$ & $\begin{array}{l}3.60 \\
2.98 \\
0.69 \\
12.86 \\
12.2 \\
49\end{array}$ & $\begin{array}{l}3.32 \\
3.08 \\
0.34 \\
16.67 \\
18.8 \\
149\end{array}$ & $\begin{array}{l}3.90 \\
6.50 \\
0.50 \\
36.67 \\
11.8 \\
34\end{array}$ \\
\hline
\end{tabular}

Table'14. Technological attributes of complete unretouched chert flakes $>5 \mathrm{~mm}$ in $\mathbf{K B}=\mathbf{A 7 0}$.

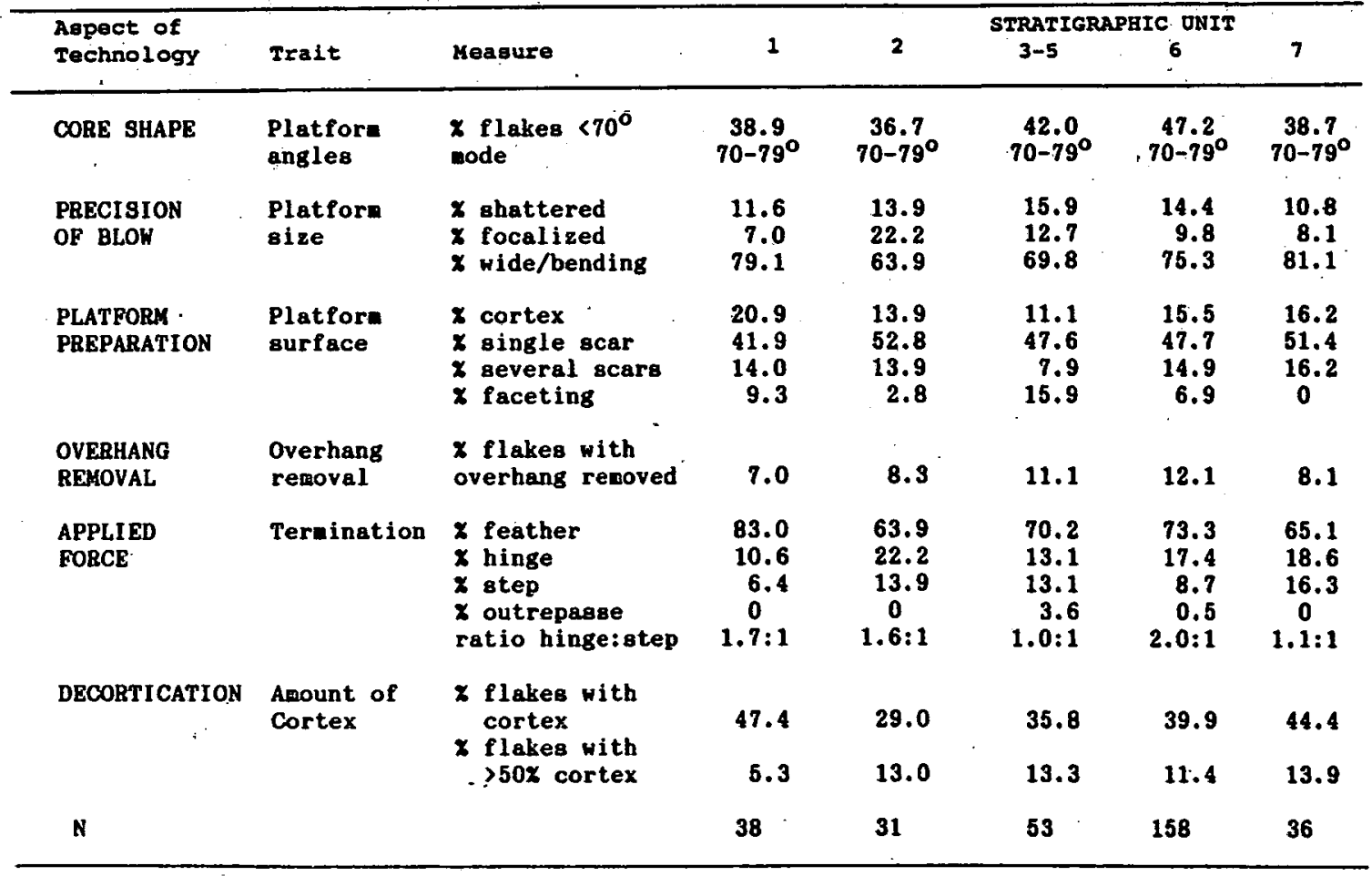


Table 15. Relationship of retouched flake type to raw material type in $\mathbf{K B}: \mathbf{A 7 0}$.

\begin{tabular}{lccccc}
\hline Implement type & Chert & Quartzite & Silcrete & Basalt & Quartz \\
\hline Backed blades & 19 & 11 & 0 & 1 & 1 \\
Elouera & 0 & 0 & 0 & 1 & 0 \\
Double backed & & 0 & 1 & 0 & 0 \\
flake & 1 & 0 & 0 & 0 & 0 \\
Burren & 3 & 0 & 0 & 0 & 0 \\
Tula & 2 & 3 & 0 & 0 & 0 \\
Burinate & 5 & 0 & 0 & 0 & 0 \\
Point & 1 & 15 & 6 & 6 & 3 \\
Amorphous & 16 & 5.7 & 7.3 & 7.7 & 3.6 \\
retouched flake & 16 & & & & \\
Percentage of & & & & & \\
flakes retouched & 6.4 & 5.7 & & & \\
\hline
\end{tabular}

Table 16. Vertical distribution of retouched flakes in RB:A70.

\begin{tabular}{rrrrrrrrrr}
\hline SU & $\begin{array}{c}\text { Backed } \\
\text { blades }\end{array}$ & Elouera & $\begin{array}{l}\text { Double } \\
\text { backed } \\
\text { flakes }\end{array}$ & Burren & Tula & Burinates & P/ES & AR \\
\hline 1 & 2 & 0 & 1 & 1 & 0 & 2 & 1 & 11 \\
2 & 4 & 0 & 0 & 2 & 1 & 1 & 0 & 4 \\
3 & 0 & 0 & 0 & 0 & 0 & 1 & 0 & 0 \\
4 & 1 & 0 & 0 & 0 & 0 & 1 & 0 & 4 \\
5 & 0 & 0 & 1 & 0 & 1 & 1 & 0 & 0 \\
6 & 12 & 1 & 0 & 0 & 0 & 0 & 0 & 17 \\
7 & 2 & 0 & 0 & 0 & 0 & 0 & 0 & 6 \\
\hline 8 & 4 & 0 & 0 & 0 & 0 & -1 & 0 & 1 \\
9 & 5 & 0 & 0 & 0 & 0 & 2 & 0 & 3 \\
10 & 1 & 0 & 0 & 0 & 0 & 0 & 0 & 2 \\
11 & 1 & 0 & 0 & 0 & 0 & 0 & 0 & 0 \\
12 & 0 & 0 & 0 & 0 & 0 & 0 & 0 & 0 \\
TOTAL & 32 & 1 & 2 & 3 & 2 & 9 & 1 & 48 \\
\hline
\end{tabular}

Table 17. Frequency of complete GOPE flakes >5mm in KB:A7O.

\begin{tabular}{cccccr}
\hline SU & $\begin{array}{c}\text { Number of } \\
\text { GOPE flakes }\end{array}$ & $\begin{array}{c}\text { Number of } \\
\text { flakes }\end{array}$ & Flakes:GOPE & $\begin{array}{c}\text { Number of } \\
\text { retouched } \\
\text { flakes }\end{array}$ & $\begin{array}{c}\text { Retouched } \\
\text { flakes } \\
\text { :GOPE }\end{array}$ \\
\hline 1 & 3 & 174 & $58: 1$ & 18 & $6.0: 1$ \\
2 & 3 & 108 & $36: 1$ & 12 & $4.0: 1$ \\
$3-5$ & 1 & 200 & $200: 1$ & 10 & $10.0: 1$ \\
6 & 17 & 591 & $34: 1$ & 30 & $1.8: 1$ \\
7 & 1 & 161 & $-5-$ & 8 & $8.0: 1$ \\
Total & 25 & 1234 & $49: 1$ & 78 & $3.1: 1$ \\
\hline
\end{tabular}


Weight: Weight was measured to the nearest 0.1 gram. Weight is a necessary piece of information with which to calculate mass (the characteristics of the raw material must also be known). Masg is an indicator of factors such as inertia and size (though not shape).

Heating: Five different criteria were used to infer. whether or not the artefact had been subjected to heating.

1. Negative potlid scars. Potlids are a concave-convex or plano-convex fragment of stone. Potlids never have a ringcrack or any other feature relating to the input of external force, but they do often have a central protruberance on the convex surface which indicates an internal initiation to the fracture. The scars left by these potlids retain all of these features in negative, typically a roughly circular depression with a small concavity at its base.

2. Crenated fracture. A wildly undulating fracture plane, initiated internaliy and without platform, ringcrack or bulbar features.

3. Crazing. A matrix of visible surface cracks, often forming a rough grid of small size.

4. Colour change. Alterations to colour resulting from heating generally tend towards increased redness and darker tones.

5. Surface lustre. A smooth highly reflecting surface caused by the fracture running through, rather than around grains, particles etc. An increase in surface lustre is often detected archaeologically when the lustrous surfaces of flake scars are superimposed upon remnants of older, rough and duller scars. Thus increases in lustre are most often vigible on granular materials such as silcrete and quartzite, where the change between original textures and heat altered one is dramatic.

Percusion length: Percussion length is the distance along the percussion axis from the ringcrack to the distal margin. In the laboratory the measurement was taken with calipers to the nẹrest millimetre.

Percussion width: Percussion width is the distance between the lateral margins, measured at right angles to the length midway between the ringcrack and the distal end. The measurement was taken with calipers to the nearest millimetre.

Thickness: Thickness, the distance between the ventral and dorsal surfaces, was measured at the intersection of the width and length. The measurement was taken with calipers to the nearest millimetre.

Platform width: The platform width is the distance across the platform from one lateral margin to another. The measurement was taken with calipers to the nearest millimetre.

Platform thickness: Platform thickness is the distance across the platform surface from the centre of the ringcrack to the dorsal face, in line with the percussion axis. The measurement was taken with calipers to the nearest millimetre. Platform thickness measures the distance of the ventral surface from the core surface. As the ventral surface is initiated at the ring crack platform thickness indicates the distance of 
the point of force application from the edge of the core.

Termination: Four types of flake terminations were defined. Three of these (feather, hinge and step) follow the definitions given by the HoHo committee (Hayden 1979:133-135). To these a fourth type of termination was added: the outrepasse, where the fracture plane (ventral ourface) curves markedly away from the core face (dorsal surface) and continues directly into the core, removing the base of the core and giving the flake a $J$ shape in longitudinal cross section.

Orerhang removal: Overhang removal is accomplished when the knapper strikes or brushes the edge of the core platform and removes small flakes from the edge. This prevents the platform from shattering. The presence or absence of small overhang removal scars was recorded.

Platform type: Platform type is a measurement of the relationship of the point of force application (PFA) to the platform area. Four categories of platform type were defined:

1 = shattered

2 = foca $11 \mathrm{red}$

3 = wide area/ bending initiation

4 = indeterminate

These platform types were defined as follows. Indeterminate meant that no certain description of platform type could be given. shattered platforms were recorded where the remnant of a platform was definitely identified but no further information could be recorded. Focalized platforms were those in which the area of the platform was less than twlce the area of the ring crack. Wide area platforms were thoge in which the area of the platform was more than twice the area of the ring crack.

\section{Platform surfacer Nine different platform surfaces were defined:}

1 = cortex

2 - incipient fracture plane

3 = shattered platform

4 - single flake scar

5 = several large flake scars

6 = faceting a series of small-scars/crushing

7 = ground

8 = faceting and grinding

9 = indeterminate

Platform angles Platform angle is the angle between the dorsal surface of the flake and the flake platform. This anglewas measured in $10^{\circ}$ units. These units were coded as fol lows:

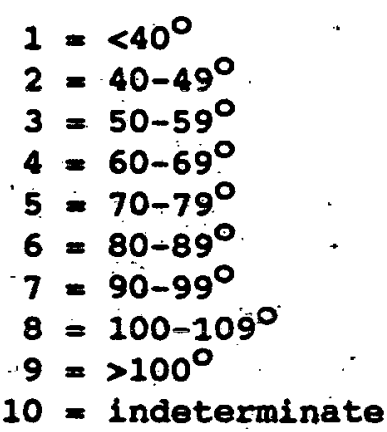


Al 1 these measurements were made using both a goniometer and a protractor in an attempt to eliminate measurement error. Because measurements were taken in $10^{\circ}$ units the measuring techniques probably record the angle with sufficient accuracy. It is the average angle of the dorsal face to the platform which was measured here.

Implement type: Nine implement types were recognised. Backed blades were small flakes steeply, and often bi-directionally, retouched along one lateral margin. Eloueras were a thicker, larger, and less regular variety of backed blade. Double backed flakes were specimens of gimilar size to backed blades but with steep, sometimes bi-directional, retouch on two lateral margins. Burrens were large thick flakes with one or both lateral margins extensively flaked to form straight or concave edges. Tulas were retouched flakes with wide platforms, pronounced bulbs, and retouched onto the dorsal face and at the distal end untli only the bulbar portion remained (Hiscock 1988:63). Burinates were retouched flakes in which flakes had been struck off along, and parallel to, the lateral or distal margins. Points were flakes which had the lateral margin and/or the proximal end retouched so that the plan shape of the specimen contract toward the distal end. Amorphous retouched flakes were those retouched flakes with small amounts of unifacial retouch and which did not clearly fall into either of the other categories of retouched flake. Axes were relatively large fragments of rock containing two ground surfaces which meet at a bevel.

Blongation index $(\mathrm{L} / w)=$ This index is a measure of the plan shape of flakes and is calculated by dividing length by width. The higher the value, the longer the flake is relative to its width.

Ventral surface area ( $W \times L)$ : This is calculated by multiplying length and width.

Parallel index (W/PW): This index is a measure of the plan ghape of flakes and is calculated by dividing the width by the platform width. A value of 1.0 indicates that the flake is square or rectangular in shape. Values 1 ess than 1.0 indicate that the flake contracts along its length away from the platform. Values greater than 1.0 , indicate that the flake expands along its length away from the platform.

Relative thickness index $(\omega / T) z$ This Index provides an Indication of the shape of the transverse cross-section, and is calculated by dividing width by thickness. Values of 1.0.indicate that the flake is as thick as it is wide. Values 1 ess than 1.0 indicate that the, flake is thicker than it is wide, and are usually associated with steep spine plane angles $\left(>52^{\circ}\right)$. Values greater than 1.0 indicate that flake thickness is small relative to width, and that spine plane angles are low $\left(<52^{\circ}\right)$. The higher the value of the index, the thinner is the flake. .

Platform area (PWxPT): This is calculated by multiplying platform width and platform thickness.

Longitudinal thinness index (T/PT): This index proviaes an indication of the shape of the longitudinal-cross-section; and is calculated by dividing thickness by platform thickness. A value of 1.0 indicates that the flake cross-section is square or rectangular in shape. Values less than 1.0 indicate that the flake contracts along its length away from the platform. Valueg greater than 1.0 indicate that the flake expands along its length away from the platform. 
Platform thickness index (PW/PT): This index provides a measure of the shape of the platform surface and, by implication, of the degree of curvature of the core face. The index ir calculated by dividing platform width by platform thickness. A value of 1.0 indicates that platform width and platform thickness are equal and the core face has an angle of approximately $52^{\circ}$. Values less than 1.0 reflect a platform which is thicker than wide, and indicates a sharply curving core face (<52 $2^{\circ}$ ). Values greater than 1.0 indicate a platform which is wider than it is thick, a result of a gradually curving core face $\left(>52^{\circ}\right)$.

Index of cross-8ectional area (HXT)/(PHxPT): This index provides an indication of the shape of flake cross-section, and is calculated by dividing the are of the trangverse cross-section by the platform area. A value of 1.0 indicates that the cross-sectional area of the flake is the same at different points along the percussion axis. Values less than 1.0 indicate that the flake contracts along its length away from the platform. Values greater than 1.0 indicate that the flake expands along its length away from the platform.

\section{REFERENCES CITED}

Allen, F. J. 1977 Fishing for wallabies: trade as a mechanism for social interaction, integration and elaboration on the central Papuan coast. In J. Friedman and M. J. Row lands (eds), The Evolution of Social Systems, pp. 419-455. London: Duckworth:

Cranfield, L. C., H. Schwarzbock, and R. W. Day 1976 Geology of the Ipswich and Brisbane 1:250,000 sheet areas. Geological survey of Queens land Report 95.

Frankel, D. 1988 Characterising change in prehistoric sequences: a view from Australia. Archaeology in Oceania 23:41-48.

Ha11, J. D. S. Gillieson and P. Hiscock 1988 Platypus Rockshelter (KB:A70), S.E. Queensland: stratigraphy, chronology and site formation. Queensland Archaeological Research - this issue

Hal 1, J. and P. Hiscock 1988 Platypü Rockghelter (KBA:70), S. E. Queensland: chronological changes in discard rates and ste usage. Queensland Archaeólogical Rsearch - this issue.

Haydèn, B. (ed) 1979 'Iithic Use-wear Analysis. New York: Academic Press.

Hill; D. 1930 The development of the Esk Series between Esk and Linvilie. Proceedings of the Royal society of Queenaland $42: 13(3): 28-48$

Hiscock, P. 1984 Preliminary report on the stone artefacts from Colless Creek, northwest Queensland. Queensland Archaeological Research 1:120-151.

Hiscock, P. 1986 Technological change' in the Hunter River valley and the interpretation of late Holocene change in Australia. Archaeology in Oceania $21: 40-50$.

Hiscock, P. 1988 A cache of tulas from the Boulia District, western Queensland. Archaeology in Oceania 23:60-70. 
Johnson, I. 1979 The getting of data. Unpublished PH.D. thesis; Dept. of Prehistory, Research School of Pacific studies, Australian National University.

Morwood, M. J. 1986 The archaeology of art: excavations at Maidenwell and Gatton shelters, southeast queensland. queensland Archaeological Research 3:88-132.

O'Flynn, M. L., K. H. Holmes and D. L. Trezise 1983 Industrial rock and mineral resources of the Brisbane and Caboolture 1:100,000 sheet area. Geological Survey of Queensland Publication 382.

Tucker, R. M. 1961 Pillow lavas in rocks of the Neranleigh-Fernvale group of south-east Queensland. Australian Journal of Science $24: 83$.

zimmerman, D. O. 1956 The geology of the Esk district with particular reference to petrography and structure. Unpublished B.SC (Hons) thesis. University of queensiand. 